\title{
A família Rubiaceae Juss. no Cariri Paraibano ${ }^{\mathbf{1}}$
}

\author{
The family Rubiaceae Juss. in the Cariri region of Paraíba
}

\author{
Maria do Céo Rodrigues Pessoa ${ }^{2,4}$ \& Maria Regina de V. Barbosa ${ }^{3}$
}

\begin{abstract}
Resumo
O Cariri Paraibano, situado numa depressão do Planalto da Borborema na Paraíba, é considerado uma das áreas prioritárias para a conservação da Caatinga. O presente trabalho teve como objetivo realizar o levantamento e caracterização das espécies de Rubiaceae presentes no Cariri Paraibano, visando contribuir com a taxonomia da família e com os estudos florísticos na região. Foram identificados 15 gêneros (Borreria, Chiococca, Cordiera, Coutarea, Diodella, Guettarda, Leptoscella, Manettia, Mitracarpus, Oldenlandia, Randia, Richardia, Spermacoce, Staelia e Tocoyena,) e 21 espécies de Rubiaceae na área. Apresenta-se uma chave para identificação das espécies bem como descrições, ilustrações e comentários sobre as espécies estudadas. Palavras-chave: caatinga, flora, semiárido.
\end{abstract}

\begin{abstract}
The Cariri region of Paraíba, situated in a depression of the Borborema plateau, is considered to be a priority area for caatinga conservation. The objective of this study was to survey the Rubiaceae of the Cariri region of Paraíba, thus contributing to our knowledge of the region's flora. Fifteen genera (Borreria, Chiococca, Cordiera, Coutarea, Diodella, Guettarda, Leptoscella, Manettia, Mitracarpus, Oldenlandia, Randia, Richardia, Spermacoce, Staelia and Tocoyena) comprising 21 species were found and identified. The study also includes a key to species and descriptions, illustrations and comments of each species studied.

Key words: caatinga, flora, semiarid.
\end{abstract}

\section{Introdução}

Rubiaceae, considerada uma das principais famílias da flora brasileira, está presente em todos os domínios fitogeográficos no país, nos quais são reconhecidos 118 gêneros e 1.347 espécies (Barbosa et al. 2010). Na Região Nordeste a família é citada entre as mais diversas e está representada por 66 gêneros e 309 espécies (Barbosa et al. 2006). Contudo, o conhecimento sobre a riqueza de Rubiaceae na Caatinga é ainda incipiente, sendo as informações oriundas principalmente de listas florísticas. Barbosa \& Zappi (2002) citam 53 taxa de Rubiaceae para o bioma, os quais variam de endêmicas (16 spp.) até predominantemente também em outros tipos de vegetação.
Na Paraíba, a família Rubiaceae foi estudada por Barbosa (1995, 1997), Pereira (1996), Pereira \& Barbosa (2004, 2006) e Melo \& Barbosa (2007), principalmente em áreas de Mata Atlântica. O conhecimento sobre a diversidade de Rubiaceae nas áreas de Caatinga paraibana é ainda restrito, apesar da reconhecida importância deste bioma que ocupa $72 \%$ do território estadual (SUDEMA 1992).

O presente trabalho teve como objetivo realizar o tratamento taxonômico das espécies da família Rubiaceae presentes em uma das regiões mais ameaçadas na Caatinga paraibana, contribuindo dessa forma para o conhecimento de sua diversidade no estado e no bioma, fornecendo subsídios para a conservação e uso sustentável da vegetação do Cariri Paraibano.

\footnotetext{
${ }^{1}$ Parte da Dissertação de Mestrado da primeira autora.

${ }^{2}$ Programa de Pós-Graduação em Biologia Vegetal, Universidade Federal de Pernambuco, Depto. Botânica, CCB, R. Prof. Nelson Chaves, s/n, Cidade Universitária, 50670-901, Recife, PE, Brasil.

${ }^{3}$ Universidade Federal da Paraíba, Centro de Ciências Exatas e da Natureza, Depto. Sistemática e Ecologia, C.P. 5065, 58051-970, João Pessoa, PB, Brasil.

${ }^{4}$ Autora para correspondência: mariadoceoster@gmail.com
} 


\section{Material e Métodos}

Área de Estudo

O Cariri Paraibano possui uma área de aproximadamente $11.689 \mathrm{Km}^{2}$, localizada numa depressão do planalto da Borborema, no centro-sul do estado da Paraíba (Moreira 1988). É considerado uma das áreas prioritárias para a conservação da Caatinga, dado o seu elevado grau de instabilidade e insuficiência de conhecimento científico (Velloso et al. 2002).

Seu relevo é bastante heterogêneo, dividido basicamente em duas unidades, terrenos dissecados e o nível da Borborema, ca. $500 \mathrm{~m}$ alt. (Lima \& Melo 1985). O clima é quente e semiárido com temperatura média anual de $26^{\circ} \mathrm{C}$ e umidade relativa do ar não ultrapassando $75 \%$ (Carvalho et al. 2000). Uma das principais características da região é a irregularidade pluviométrica, com chuvas concentradas e a ocorrência de secas prolongadas, podendo ocorrer médias anuais extremas de $350 \mathrm{~mm} /$ ano, os mais baixos índices pluviométricos do Brasil (Moreira, 1988; Carvalho et al. 2000). A vegetação é predominantemente de caatinga, podendo ser considerada, em áreas bem preservadas, diversa e rica em espécies (Barbosa et al. 2007).

Assim como em todo o bioma Caatinga, o Cariri apresenta poucas Unidades de Conservação, principalmente as de proteção integral (SUDEMA 1992), e as áreas remanescentes de vegetação nativa em bom estado de conservação são cada vez mais escassas.

\section{Metodologia}

O trabalho de campo teve início em julho de 2007 e se estendeu até julho de 2008. Nesse período foram realizadas observações e coletas mensais de material botânico fértil para posterior estudo e registro em herbário, abrangendo tanto a estação seca quanto a chuvosa. As coletas foram realizadas, de forma aleatória e direcionadas aos espécimes da família, em nove municípios do Cariri Paraibano (Cabaceiras, Camalaú, Caturité, Monteiro, São João do Cariri, São João do Tigre, São José dos Cordeiros, Serra Branca e Sumé), priorizando áreas que apresentassem remanescentes de vegetação em bom estado de conservação e/ou que fossem Unidades de Conservação. O material coletado foi herborizado e depositado no herbário Lauro Pires Xavier (JPB), com duplicatas no herbário Geraldo Mariz (UFP).

A identificação dos taxa foi efetuada após a análise morfológica detalhada do material botânico, com o auxílio da literatura especializada (revisões e/ou estudos taxonômicos), consulta às descrições originais das espécies, bem como a tipos e/ou fotografias dos tipos e coleções históricas de outros herbários. Foram consultados os herbários CEPEC, EAN, HRB, HUEFS, IPA, JPB, PEUFR, RB, UESC e UFP, a fim de verificar a distribuição geográfica das espécies, dados acerca da floração e frutificação, bem como informações complementares sobre o habitat e forma de vida das espécies.

As descrições, chave e o tratamento taxonômico foram baseados exclusivamente no material coletado no Cariri Paraibano, com exceção de Manettia cordifolia Mart. e Randia armata Müll. Arg. que tiveram suas descrições complementadas com auxílio da literatura (Macias 1998; Schumann 1889, Jung-Mendaçolli \& Anunciação 2007), e Guettarda sericea cuja descrição contemplou material adicional de outra área. Para a confecção das pranchas foram selecionados e utilizados caracteres diagnósticos ou diferenciais dos táxons. A terminologia utilizada nas descrições morfológicas baseou-se, principalmente em Radford et al. (1974).

\section{Resultados e Discussão}

Foram identificadas no Cariri Paraibano 21 espécies pertencentes a 15 gêneros. Borreria G. Mey.e Mitracarpus Zucc. foram os gêneros que apresentaram maior riqueza de espécies (três cada), seguidos por Guettarda L. e Tocoyena Aubl. (duas cada).

Dentre as espécies estudadas, de acordo com Barbosa \& Zappi (2002), são endêmicas com distribuição ampla na caatinga: Guettarda angelica Mart. ex Müll. Arg., G. sericea Müll. Arg., Leptoscela ruellioides Hook. f. e Oldenlandia tenuis K. Schum.. Mitracarpus baturitensis Sucre é predominantemente de caatinga, mas ocorre em outros tipos de vegetação (Souza et al. 2010). Borreria scabiosoides Cham. \& Schltdl., Coutarea hexandra (Jacq.) K. Schum., Diodella apiculata (Willd. ex Roem. \& Schult.) Delprete, Mitracarpus frigidus (Willd. ex Roem. \& Schult.) K. Schum., Richardia grandiflora (Cham. \& Schltdl.) Steud., Staelia virgata (Link ex Roem. \& Schult.) K.Schum., Tocoyena formosa (Cham. \& Schltdl.) K. Schum. e T. sellowiana (Cham. \& Schltdl.) K. Schum., ainda de acordo com Barbosa \& Zappi (2002), são espécies predominantemente de outros tipos de vegetação, mas que também ocorrem na caatinga. As demais espécies (Borreria brownii (Rusby) Standl., B. verticillata (L.) G. Mey., Chiococca alba (L.) Hitchc., Cordiera rigida (K. Schum.) Kuntze, Manettia cordifolia Mart., Mitracarpus salzmaniannus DC., Randia armata (Sw.) DC. e Spermacoce tenuior L.), apesar de não terem sido referidas por Barbosa \& Zappi (2002) para a Caatinga, embora 
predominantemente de outros tipos de vegetação, também ocorrem no bioma.

Quanto ao status de conservação nenhuma das espécies estudadas foi considerada como ameaçada, de acordo com os critérios da IUCN (2001).

\section{Rubiaceae Juss.}

\section{Tratamento Taxonômico}

Árvores, arvoretas, arbustos, subarbustos escandentes ou não, ou ervas, dioicas ou monoicas, armadas ou inermes, caules e ramos cilíndricos ou angulosos, lisos ou estriados. Estípulas interpeciolares, inteiras ou fimbriadas, livres ou unidas formando uma bainha, persistentes ou caducas. Folhas simples, opostas, sésseis ou pecioladas, lineares, elípticas, lanceoladas, oblongo-lanceoladas, obovado-lanceoladas, oblongas, ovadas ou obovadas, com ou sem domácias.
Inflorescências sésseis ou pedunculadas, racemosas ou cimosas, terminais, subterminais ou axilares, com ou sem brácteas. Flores (3)4-6-meras, andróginas ou unissexuais, sésseis ou pediceladas, actinomorfas, raro zigomorfa (Coutarea) com prefloração valvar, imbricada ou contorta; cálice subulado, cupuliforme, truncado, campanulado, persistente ou caduco; corola tubulosa, clavado-tubulosa, infundibuliforme, hipocrateriforme ou campanulada, branca, alvoamarelada, rubra, lilás, rosada, ou vinácea. Estames exsertos ou inclusos, alternos aos lobos da corola, epipétalos. Ovário ínfero, bi-multilocular, um a muitos óvulos por lóculo, estilete inteiro ou trífido, exserto ou incluso; estigma capitado, capitado-bilobado, bilobado, bífido, bifurcado-sagitado ou bilamelado. Frutos deiscentes ou não, bagas, drupas, cápsulas ou esquizocarpos.

\section{Chave para identificação das espécies de Rubiaceae presentes no Cariri Paraibano}

1. Árvores, arvoretas, arbustos ou subarbustos eretos ou escandentes; estípulas livres ou conatas apenas na base, triangulares ou deltoides

2. Arbustos ou subarbustos escandentes

3. Flores 4-meras, corola clavado-tubulosa, estigma bífido, lóculos do ovário pluriovulados; cápsulas septicidas, oblongas ....................................................... 11. Manettia cordifolia

3'. Flores 5-meras, corola campanulada, estigma bilobado, lóculos do ovário uniovulados; drupas orbiculares

4. Chiococca alba

2'. Árvores, arvoretas ou arbustos eretos.

4. Plantas dioicas; flores unissexuadas.

5. Arvoreta ou arbusto com ramos armados no ápice (4 espinhos); pecíolo 5-7 mm compr. ....... 16. Randia armata

5'. Arbusto inerme; pecíolo 0,3-3 mm compr.

5. Cordiera rigida

4'. Plantas monoicas; flores andróginas.

6. Corola campanulada ou infundibuliforme; fruto comprimido dorsiventralmente.

7. Corola infundibuliforme, maior do que $3 \mathrm{~cm}$ compr., tubo geralmente curvo; cápsula loculicida 6. Coutarea hexandra

7'. Corola campanulada, até $1 \mathrm{~cm}$ compr., tubo não curvo; drupa

4. Chiococca alba

6'. Corola tubulosa ou hipocrateriforme; fruto não comprimido dorsiventralmente.

8. Cimas dicotômicas; ovário tetralocular, uniovulado; drupas oblongas ou globosas

9. Flores 4-meras, estames inseridos na porção mediana do tubo; drupa oblonga

9. Guettarda sericea

9'. Flores 5-6 meras, estames inseridos junto à fauce; drupa globosa

8. Guettarda angelica

8'. Dicásios; ovário bilocular, pluriovulado; bagas.

10. Folhas com indumento em ambas as faces; estípulas caducas

20. Tocoyena formosa

10'. Folhas glabras, lustrosas em ambas as faces; estípulas persistentes

21. Tocoyena sellowiana

1'. Ervas ou subarbustos eretos, decumbentes ou prostrados; estípulas conatas formando uma bainha fimbriada

11. Lóculos do ovário pluriovulados

12. Cápsula loculicida com deiscência apical

15. Oldenlandia tenuis 
12’. Cápsula septicida 10. Leptoscela ruellioides

11'. Lóculos do ovário uniovulados.

13. Ovário trilocular, estilete trífido; esquizocarpos com três mericarpos ..... 17. Richardia grandiflora

13'. Ovário bilocular, estilete inteiro; esquizocarpos com dois mericarpos ou cápsulas septicidas.

14. Esquizocarpos com dois mericarpos 7. Diodella apiculata 14'. Cápsulas septicidas.

15. Corola ciatiforme; sementes com numerosos sulcos tranversais ... 1. Borreria brownii

15'. Corola infundibuliforme, hipocrateriforme ou tubulosa; sementes sem sulcos transversais

16. Cápsulas com deiscência circuncisa ou transverso-oblíqua.

17. Frutos com deiscência transverso-oblíqua, separando-se por duas valvas apicais 19. Staelia virgata

17'. Frutos com deiscência circuncisa, separando-se por uma porção apical em forma de mitra.

18. Sementes com depressão ventral em forma de "Y" invertido. 14. Mitracarpus salzmanianus

18'. Sementes com depressão ventral em forma de "X".

19. Erva ereta, $8-40 \mathrm{~cm}$ alt.; cápsula globosa

12. Mitracarpus baturitensis

19'. Subarbusto 0,4-1 m alt.; cápsula obcônica

13. Mitracarpus frigidus

16’. Cápsulas com deiscência longitudinal.

20. Erva palustre; caule inflado

2. B. scabiosoides

20'. Erva ou subarbusto terrestre; caule não inflado.

21. Estigma bilobado; fruto separando-se em dois mericarpos, ambos deiscentes no ápice 3. Borreria verticillata

21 '. Estigma capitado; fruto separando-se em dois mericarpos, um indeiscente e outro deiscente, abrindo-se parcialmente do ápice até a região mediana

18. Spermacoce tenuior

1. Borreria brownii (Rusby) Standl., Publ. Field Mus. Nat. Hist., Bot. Ser. 7: 333. 1931. Fig.1a-c Erva, ereta, 20-35 cm alt., ramificada; caule anguloso, verde, pubescente. Bainha estipular 3-4,3 $\mathrm{mm}$ compr., fimbriada, pubérula ou pubescente, 7-9-(11)-laciniada, lacínios 3,3-4 mm compr., glandulosos. Folhas opostas, sésseis; lâmina 6-7 × 2,5-2,8 cm, elíptica ou lanceolada, ápice agudo a cuspidado, base atenuada, margem serreada a serrilhada, membranácea, face superior com tricomas longos e esparsos, face inferior estrigosa ao longo das nervuras; nervura principal proeminente, nervuras secundárias 4-6 pares. Glomérulos terminais ou subterminais, sésseis, paucifloros; 2 brácteas foliáceas. Flores andróginas, 4-meras, subsésseis; botões florais com ápice agudo. Cálice subulado, 4-laciniado, lacínios subiguais $0,7-1,6 \mathrm{~mm}$ compr. ou desiguais dois a dois, os maiores $0,7-1,6 \mathrm{~mm}$ compr., os menores ca. 0,8 mm compr., glabro, ápice agudo, margem pectinado-ciliada; hipanto ca. $2,3 \mathrm{~mm}$ compr., turbinado, piloso no terço superior.
Corola ciatiforme, prefloração valvar, branca, externamente pubérulo-papilosa, internamente pubérula com anel de tricomas moniliformes junto à fauce; tubo estreito, 1,5-1,7 mm larg.; lobos 0,8-1 mm compr., oblongos. Estames exsertos, inseridos junto à fauce; filetes $0,3-0,4 \mathrm{~mm}$ compr.; anteras ca. 0,4 mm compr. Ovário bilocular, lóculo uniovulado; estilete 1,8-2 mm compr., inteiro, exserto, glabro; estigma capitado-bilobado; disco inconspícuo, bilobado, glabro. Cápsula septicida, ca. $3 \mathrm{~mm}$ compr., elipsoide, pilosa no terço superior, carpelos unidos na base, deiscentes no ápice; lobos do cálice persistentes. Sementes 1,6-2 mm compr., oblongas, exotesta fovéoloreticulada, face dorsal com numerosos sulcos transversais, face ventral com sulco longitudinal amplo, parcialmente coberto por estrofíolo.

Material selecionado: PARAÍBA: Monteiro, Serra de Jabitacá, 12.VI.2008, fl. e fr., M.C. Pessoa et al. 437 (JPB). Serra do Perú, 21.V.2008, fl. e fr., M.C. Pessoa \& P.C. Gadelha-Neto 386 (JPB). São João do Tigre, 17.V.2008, fl. e fr., M.C. Pessoa \& J.R. Lima 360 (JPB). 

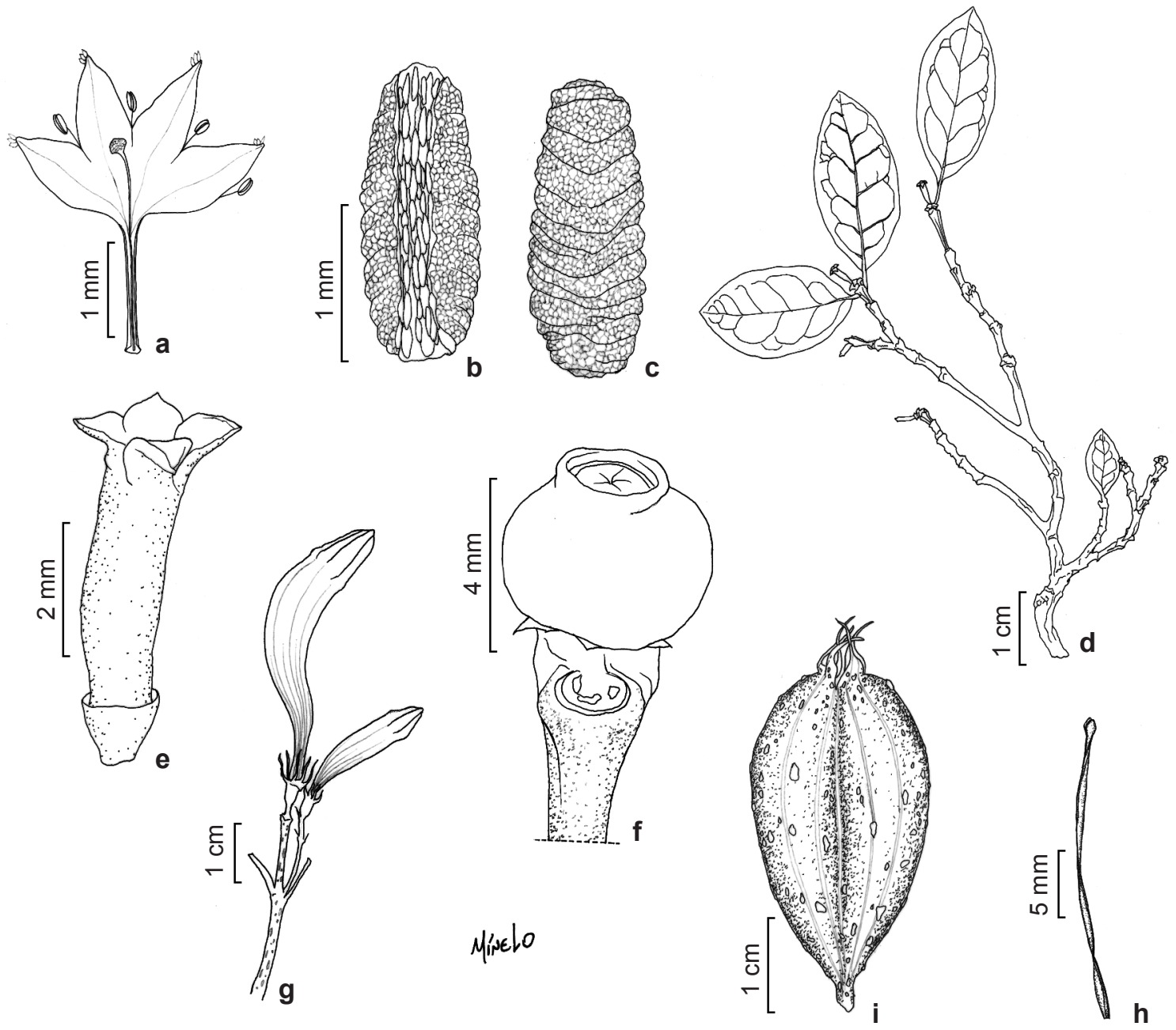

Figura 1 - a-c. Borreria brownii - a. corola em secção longitudinal; b. semente, face ventral; c. semente, face dorsal; d-f. Cordiera rigida - d. ramo florífero; e. flor estaminada. f. fruto; g-i. Coutarea hexandra - g. botões florais; h. estilete; i. fruto. (a-c. M.C.Pessoa 437; d-e. M.C.Pessoa 233; f. M. C. Pessoa 248; g-h. P.C.Gadelha-Neto 363; i. M. C.Pessoa 534).

Figure 1 - a-c. Borreria brownii - a. longitudinal cut corolla; b. seed, ventral face; c. seed, dorsal face; d-f. Cordiera rigida - d. fertile branch; e. male flower. f. fruit; g-i. Coutarea hexandra-g. buds; h. style; i. fruit. (a-c. M.C.Pessoa 437; d-e. M. C. Pessoa 233; f. M.C.Pessoa 248; g-h. P.C.Gadelha-Neto 363; i. M. C. Pessoa 534).

Borreria brownii está inserida na Serie Laeves a qual reúne espécies com sementes transversalmente sulcadas, podendo variar o número de sulcos. Ocorre no México, Guatemala, Costa Rica, Venezuela, Brasil, Bolívia e Argentina (Cabral \& Bacigalupo 1999). No Brasil tem referência para o Cerrado e a Caatinga. No Cariri paraibano foi coletada apenas na caatinga sensu stricto. Floresce e frutifica de maio a julho. Distingue-se facilmente das demais espécies de Borreria que ocorrem no Cariri, por apresentar corola ciatiforme com tubo muito estreito na base e os tricomas no ápice dos lobos.
2. Borreria scabiosoides Cham. \& Schltdl., Linnaea 3: 318. 1828.

Erva palustre, ereta ou decumbente, $0,8-1,5$ $\mathrm{m}$ alt., ramificada; caule cilíndrico, vináceo ou verde-avermelhado, inflado na região dos nós, glabro. Bainha estipular 6-8 mm compr., fimbriada, glabra, 4-8 laciniada, lacínios 5,3-6 mm compr., não-glandulosos. Folhas opostas, sésseis, lâmina 6-8 $\times 0,5-0,8 \mathrm{~cm}$, linear a lanceolada, ápice agudo, base atenuada, margem revoluta, cartácea, escabra em ambas as faces; nervura principal proeminente e com dentículos na face inferior, nervuras secundárias 
3-4 pares. Glomérulos axilares ou terminais, sésseis, multifloros; 2 brácteas foliáceas. Flores andróginas, 4-meras, sésseis; botões florais com ápice obtuso. Cálice subulado, 4-laciniado, lacínios iguais entre si, 2-2,5 mm compr., pubérulo a escabro, margem ciliada; hipanto 2,5 mm compr., oblongo, piloso no ápice. Corola infundibuliforme, prefloração valvar, branca, lilás no ápice dos lobos, externamente pubérulo-papilosa, internamente com um anel delgado de tricomas no terço inferior do tubo; tubo 2,5-4 mm compr.; lobos 2-2,3 mm compr., triangulares. Estames exsertos, inseridos à fauce; filetes 1-2 mm compr., glabros; anteras 1-1,2 mm compr. Ovário bilocular, lóculo uniovulado; estilete 5-7 mm compr., inteiro, exserto, glabro; estigma capitado-bilobado; disco bipartido, glabro. Cápsula septicida 3-4 mm compr., oblonga, pubérula a escabra, 2 mericarpos, deiscentes do ápice até a região mediana ou totalmente deiscentes; lobos do cálice persistentes. Sementes ca. 2,3 mm compr., lineares a oblongas, exotesta foveolada, sulcos transversais ausentes, sulco longitudinal coberto por estrofíolo. Material examinado: PARAÍBA: Monteiro, 11.VI.2008, fl. e fr., M.C. Pessoa et al. 406 (JPB).

Borreria scabiosoides tem distribuição neotropical (Andersson 1992; Lorence 1999). É uma espécie comumente encontrada em ambientes úmidos na Mata Atlântica, Floresta Amazônica, Caatinga e Cerrado. No Cariri foi encontrada uma população às margens de uma lagoa temporária, florida e frutificada, no mês de junho. É fácil diferenciá-la das demais espécies do gênero Borreria que ocorrem na região por ser a única espécie palustre.

\section{Borreria verticillata (L.) G. Mey., Prim. Fl. Esseq.} 83. 1818.

Erva ou subarbusto ereto, $15-60 \mathrm{~cm}$ alt., ramificada; caule anguloso, tetrangular, verde, verde-amarelado a castanho, fistuloso, pubérulo, glabrescente próximo à base, denticulado ao longo dos ângulos. Bainha estipular, 1,6-3,3 mm compr., fimbriada, pubérula a pilosa, 7-10 laciniada, lacínios 3-8 mm compr., glandulosos. Folhas opostas, sésseis; lâmina foliar 2,2-8,3 × 0,5-2 cm, estreitamente elíptica, elíptica ou lanceolada, ápice apiculado, agudo a acuminado, base atenuada, margem denticulada, membranácea a cartácea, face superior escabra a estrigosa, face inferior esparsamente estrigosa, ligeiramente pilosa ao longo da nervura principal; nervura principal bastante proeminente na face inferior, nervuras secundárias 2-3-(6) pares. Glomérulos axilares ou terminais, sésseis ou subsésseis, multifloros; 2-4 brácteas foliáceas. Flores andróginas, 4-meras, sésseis ou subsésseis; botões florais com ápice obtuso. Cálice subulado, 2-4-laciniado, lacínios subiguais 1,2-2,5 mm compr., ou desiguais dois a dois, os maiores ca. $2 \mathrm{~mm}$ compr., os menores ca. 1,2 mm compr., pubescentes, margem longo-laciniada; hipanto $1-2 \mathrm{~mm}$ compr., oblongo, pubérulo. Corola infundibuliforme, prefloração valvar, branca, externamente glabra ou papilosa, internamente com um anel de tricomas na fauce; tubo $0,5-1,8 \mathrm{~mm}$ compr., lobos $0,7-1,7 \mathrm{~mm}$ compr., triangulares.. Estames exsertos, inseridos junto à fauce; filetes $0,6-1,3 \mathrm{~mm}$ compr., glabros; anteras $0,5-1,2 \mathrm{~mm}$ compr. Ovário bilocular, lóculo uniovulado; estilete $1,5-3,8 \mathrm{~mm}$ compr., inteiro, exserto, glabro; estigma bilobado; disco bipartido, papiloso. Cápsula septicida, 1,8-3 $\mathrm{mm}$ compr., elipsoide, pubérula a escabra, carpelos unidos na base, deiscentes no ápice; lobos do cálice persistentes. Sementes 1-1,5 mm compr., oblongas a elipsoides, exotesta foveolada, sulco transversal ausente, sulco longitudinal amplo coberto por estrofíolo.

Material selecionado: PARAÍBA: São João do Tigre, APA das Onças, 17.V.2008, fl. e fr., M.C. Pessoa \& J. R. Lima 359 (JPB); 13.VI.2008, fl. e fr., M.C. Pessoa et al. 443 (JPB).

Borreria verticillata é uma espécie ruderal de distribuição neotropical (Andersson 1992). No Cariri paraibano foi coletada apenas no município de São João do Tigre, em áreas perturbadas. É conhecida popularmente como vassourinhade-botão. Caracteriza-se pelas inflorescências bracteadas, e frutos capsulares com deiscência septicida, separando-se em duas porções deiscentes.

4. Chiococca alba (L.) Hitch., Annual Rep. Missouri Bot. Gard. 4: 94. 1893.

Arbusto ereto ou escandente, $1-1,5 \mathrm{~m}$ alt.; ramos cilíndricos, espessos nos nós, estriados, castanhoacinzentados, glabros a glabrescentes. Estípulas 2-6,5 mm compr., inteiras, triangulares, ápice agudo a aristado, glabrescentes ou pubérulas externamente, glabras internamente, com coléteres. Folhas opostas; lâmina 4-6,5 × 2-3,6 cm, oblongo-ovada, ápice agudo, base atenuada, margem inteira, membranácea, face superior glabra, face inferior pubescente; nervura principal pouco proeminente, nervuras secundárias 3-5 pares; pecíolo 1,3-2 mm compr., pubescente. Racemos axilares, 3-6 flores dispostas unilateralmente; pedúnculo $0,5-2 \mathrm{~cm}$ compr., glabro a pubescente. Flores andróginas, 5-meras, pedicelo 1,2-2,5 mm compr., glabro a pubescente; botões florais com ápice agudo. Cálice subulado, 
5-laciniado, lacínios 1-1,5 mm compr., hirsuto, margem longo-ciliada; hipanto 1,5-2 mm compr., globoso, glabro. Corola campanulada, prefloração imbricada, amarelada, glabra externamente e internamente com um anel de tricomas no terço inferior; tubo 4,5-5 mm compr., lobos 1,2-2,2 $\mathrm{mm}$ compr., triangulares. Estames inclusos, inseridos na base do tubo, filetes 2-2,5 mm compr., viloso; anteras $3,5 \mathrm{~mm}$ compr. Ovário bilocular, lóculo uniovulado, comprimido dorsiventralmente; estilete 4-6 mm compr., inteiro, cilíndrico, exserto, glabro; estigma bilobado, ligeiramente anguloso; disco bipartido, glabro. Drupa, 4,8-5,7 mm compr., orbicular, comprimida dorsiventralmente, glabra; lobos do cálice persistentes. Sementes 4-4,6 mm compr., elípticas, comprimidas dorsiventralmente, lisas a papilosas.

Material examinado: PARAÍBA: Monteiro, 21.V.2008, fl. e fr., M.C. Pessoa \& P.C. Gadelha-Neto 390 (JPB).São João do Tigre, 13.06.2008, fl. e fr., M.C. Pessoa et al. 440 (JPB).

Chiococca alba está presente nas Américas do Norte, Central e do Sul (Andersson 1992). No Brasil, ocorre desde Pernambuco até o Rio Grande do Sul (Zappi \& Stannard 1995; Barbosa 1996; Jung-Mendaçolli 1999), em quase todos os domínios fitogeográficos (Barbosa et al. 2010). No Cariri paraibano ocorre na caatinga sensu stricto. Foi encontrada com flores e frutos em junho e julho. Caracteres diagnósticos importantes de Chiococca alba são os racemos axilares, pedunculados, dispostos unilateralmente e os frutos comprimidos dorsiventralmente, alvos na maturação.

5. Cordiera rigida (K. Schum.) Kuntze, Rev. Gen. Pl. 1: 279. 1891.

Fig. 1d-f

Arbusto dioico, 1,5-5,7 m alt.; ramos cilíndricos, tortuosos, castanho-acinzentados, glabros, com exsudado resinoso no ápice. Estípulas imbricadas no ápice, 1,4-3 mm compr., inteiras, triangulares, com ápice aristado, pubescentes a escabras. Folhas opostas, lâmina 2-9(11) × $1,7-5,3(6) \mathrm{cm}$, oblongo-lanceolada a elíptica, raro orbicular, ápice agudo a obtuso, base aguda a obtusa, margem ligeiramente crenada, coriácea, glabra ou pubérula em ambas as faces; nervura principal proeminente, nervuras secundárias 5-7 pares; pecíolo 0,3-3 $\mathrm{mm}$ compr., escabro a pubescente na base. Dicásios terminais congestos, subsésseis, paucifloros. Flores masculinas sésseis ou subsésseis, 3-(7-11), 4-5 meras; botões florais com ápice agudo. Cálice truncado, $0,6-0,8 \mathrm{~mm}$ compr., escabro; hipanto $0,5-0,7 \mathrm{~mm}$ compr., cupuliforme, pubérulo-papiloso a escabro. Corola tubulosa, prefloração contorta, vinácea, glabra internamente, escabra a verrucosa externamente; tubo 5-9 mm compr., lobos 1,8-2,5 mm compr., suborbiculares a deltoides, ápice agudo, pubérulopapiloso, revoluto. Estames inclusos, inseridos na porção mediana do tubo, sésseis a subsésseis; anteras 4-5 mm compr.; estilete 2,8-4,3 mm compr., inteiro, incluso; estigma bifurcado-sagitado; disco inteiro, glabro. Flores femininas 1-3, 4-5 meras, sésseis; botões florais com ápice agudo-arredondado. Cálice cupuliforme, 0,6-1 mm compr., escabro; hipanto ca. $2 \mathrm{~mm}$ compr., turbinado, pubérulopapiloso a escabro. Corola tubulosa, prefloração contorta, vinácea, glabra internamente, escabra a verrucosa externamente; tubo ca. $3 \mathrm{~mm}$ compr., lobos 1-1,3 mm compr., suborbiculares a deltoides. Estames inclusos, inseridos na porção mediana do tubo, sésseis a subsésseis; anteras 2-5 mm compr. Ovário bilocular, lóculo biovulado; estilete 3-3,5 mm compr., inteiro, incluso; estigma 1,2-2,3 mm compr., bifurcado-sagitado; disco inteiro, glabro. Baga, 4-5 mm compr., globosa, glabra a pubérulopapilosa; lobos do cálice persistentes. Sementes 3,6-4,5 $4 \mathrm{~mm}$ compr., subcilíndricas a discoides, planas, exotesta estriada.

Material selecionado: PARAÍBA: Cabaceiras, 20.III.2008, fl. e fr., M.C. Pessoa \& J.R. Lima 288 (JPB). Caturité, 12.VII.2008, M.C. Pessoa \& J.R. Lima 510 (JPB). São José dos Cordeiros, RPPN Fazenda Almas, 03.XII.2007, fr., M.C. Pessoa \& J.R. Lima 248 (JPB). Serra Branca, 17.X.2007, fl., M.C. Pessoa et al. 233 (JPB).

Cordiera rigida é endêmica do Brasil, ocorrendo no Cerrado e na Caatinga (Barbosa et al. 2010). No Cariri paraibano, ocorre na caatinga sensu stricto, nas margens de rios e lajedos. Diferencia-se das demais espécies de Rubiaceae encontradas no Cariri por apresentar flores unissexuadas, com corola carnosa, vinácea.

\section{Coutarea hexandra (Jacq.) K. Schum., Fl. Bras.} 6(6): 196. 1889.

Fig. 1g-i

Arvoreta 2-4 m alt.; ramos cilíndricos, espessos nos nós, estriados, castanho-acinzentados a acinzentados, lenticelados, principalmente no ápice, glabros. Estípulas 2-3 mm compr., inteiras, triangulares, ápice agudo, ciliadas na margem, internamente pilosas; coléteres presentes. Folhas opostas; lâmina foliar 4,5-7,5 × 2,5-4,4 cm, lanceolado-ovada a ovada, ápice acuminado, base atenuada, margem revoluta, cartácea, face superior glabra, face inferior pubescente; nervura principal proeminente na face inferior, nervuras secundárias 3-5 pares; pecíolo $0,5-0,1 \mathrm{~cm}$ compr., 
hirsuto. Cimas axilares ou terminais, paucifloras, 1-3 flores; pedúnculo 1,7-3 cm compr., glabro a pubescente. Flores andróginas, 6-meras, pedicelo 0,3-0,5 cm compr., glabro; botões florais com ápice agudo, geralmente com tubo curvo. Cálice subulado, 6-laciniado, lacínios subiguais, 4,5-5 $\mathrm{mm}$ compr., pubérulo a escabro externamente, internamente tomentoso, com coléteres; hipanto 3-4 mm compr., infundibuliforme, pubescente. Corola infundibuliforme, prefloração imbricada, alvorosada, pubérula internamente, escabra a pubérula externamente; tubo 2,8-3 cm compr., geralmente curvo, lobos 7-8 mm compr., triangulares. Estames exsertos, inseridos na base da corola; filetes ca. $2 \mathrm{~cm}$ compr., pubérulos mais próximo da base; anteras 0,9-1 cm compr. Ovário bilocular, lóculo pluriovulado; estilete ca. 2,6 cm compr., inteiro, exserto, filiforme, espiralado, ligeiramente estriado, glabro; estigma bífido; disco inteiro, glabro. Cápsula loculicida, 1,4-2,8 × 1,1-1,5 mm, obovada, comprimida dorsiventralmente, pubescente, lenhosa, com estrias proeminentes, lenticeladas; lobos do cálice persistentes. Sementes 0,5-0,8 cm compr., oblongas, aladas, alas inteiras, membranáceas.

Material selecionado: PARAÍBA: Cabaceiras, 13.VII.2008, fr., M.C. Pessoa et al. 534 (JPB). Monteiro, 22.V.2008, fr., M.C. Pessoa \& P.C. Gadelha-Neto 400 (JPB).

Material adicional: PARAÍBA: Sousa, 05.II.1993, fl., P.C. Gadelha-Neto 363 (JPB).

Coutarea hexandra tem distribuição neotropical, ocorrendo no México, América Central e do Sul (Andersson 1992, Lorence 1999). No Brasil ocorre em todos os domínios fitogeográficos exceto no Pampa (Barbosa et al. 2010). No Cariri paraibano ocorre na caatinga stricto sensu. Floresce e frutifica de fevereiro a julho. Caracteriza-se por apresentar ramos lenticelados, corola infundibuliforme, com tubo curvo e frutos lenhosos comprimidos dorsiventralmente. É conhecida popularmente como "quina-quina".

7. Diodella apiculata (Willd. ex Roem. \& Schult.) Delprete, Fl. Ilustr. Catarinense 1: 169. 2004.

Erva ereta, 0,10-1 m alt., ramificada; caule anguloso, verde, levemente estriado, hirsuto. Bainha estipular 1,2-4,5 mm compr., fimbriada, hirsuta, 7-9 laciniada, lacínios 3,7-6,8 mm compr., não glandulosos. Folhas opostas, sésseis; lâmina $1,7-4,5 \times 0,3-0,8 \mathrm{~cm}$, linear-lanceolada, ápice agudo, mucronado, base atenuada, margem revoluta, membranácea, face superior escabra, com tricomas longos e brilhantes, face inferior escabra, hirsuta ao longo da nervura principal; nervura principal proeminente, nervuras secundárias 2-4 pares. Glomérulos axilares, 1-3 (4) flores, sésseis; 2 brácteas foliáceas. Flores andróginas, 4-meras, subsésseis; botões florais com ápice agudo. Cálice subulado, 4-laciniado, lacínios subiguais, 1,5-2 mm compr., pubérulo ou escabro, margem ciliada; hipanto 1,3-2,5 mm compr., turbinado, densamente piloso. Corola infundibuliforme, prefloração valvar, branca a lilás, externamente pubérula, internamente com anel de tricomas na base; tubo 2,5-4 mm compr., lobos 1,5-3 mm compr., ovado-triangulares. Estames exsertos, inseridos juntos à fauce; filetes 0,5-0,6 mm compr., glabros; anteras 0,5-0,7 mm compr.. Ovário bilocular, lóculo uniovulado; estilete 3-4 mm compr., inteiro, exserto, glabro; estigma capitado; disco inteiro, glabro. Esquizocarpo 3-3,5 mm compr., subobovado a obovado, 2 mericarpos indeiscentes, híspidos; persistentes. Sementes 1,5-1,8 cm compr., obovadas, plano-convexas, exotesta estriada, sulcadas ao redor do estrofíolo. Material selecionado: PARAÍBA: Cabaceiras, 22.IX.2007, fl. e fr., M.C. Pessoa et al. 212 (JPB). Camalaú, 16.V.2008, fl. e fr., M.C. Pessoa \& J.R. Lima 347 (JPB). Caturité, 16.V.2008, fl. e fr., M.C. Pessoa \& J.R. Lima 342 (JPB). Monteiro, 11.VI.2008, fl. e fr., M.C. Pessoa et al. 413 (JPB). São João do Cariri, 26.XI.2007, fr., M.C. Pessoa \& J.R. Lima 221 (JPB). São João do Tigre, 17.V.2008, fl. e fr., M.C. Pessoa \& J. R. Lima 352 (JPB). São José dos Cordeiros, 16.IV.2008, fl. e fr., M.C. Pessoa \& J.R. Lima 309 (JPB); Serra Branca, 28.IV.2008, fl. e fr., M.C. Pessoa \& J.R. Lima 314 (JPB).

Diodella Small diferencia-se de Diodia L. pela corola infundibuliforme ( $v s$. hipocrateriforme), estigma capitado ( $v s$. bífido), frutos esquizocárpicos com mericarpos caducos ( $v s$. frutos indeiscentes e persistentes) (Cabral \& Bacigalupo 2005; Bacigalupo \& Cabral 2006). Diodella apiculata tem ampla distribuição na região neotropical, do México até o Paraguai (Andersson 1992). No Brasil ocorre em todas as regiões. No Cariri paraibano foi coletada na caatinga sensu stricto, em áreas ciliares e sobre lajedos. Floresce e frutifica de abril a outubro. Caracteriza-se pelas folhas com ápice mucronado e por apresentar esquizocarpos subobovados.

8. Guettarda angelica Mart. ex Müll. Arg., Flora $58: 450.1875$.

Fig. 2a

Arbusto, 0,6-4,5 m alt.; ramos cilíndricos, castanho-acinzentados, lenticelados, glabros, hirsutos quando jovens. Estípulas livres, persistentes, 2-8 $\mathrm{mm}$ compr., inteiras, triangulares, caudadas, externamente pubérula ou hirsuta, internamente com coléteres. Folhas opostas; lâmina 
1,8-12 × 1,3-4 cm, lanceolada, ápice agudo, base aguda raro obtusa, margem crenada, papirácea a cartácea, discolor, face superior pubérula, face inferior serícea; nervura principal proeminente, nervuras secundárias 7-9-(11) pares; pecíolo 0,5-2 cm compr., hirsuto. Cimas dicotômicas axilares, 7-9-(12) flores; pedúnculo 0,6-5,5 cm compr., hirsuto. Flores andróginas, 5-6 meras, sésseis; botões florais com ápice obtuso. Cálice truncado, 1,5-3 mm compr., com 1 lobo 03-0,8 mm compr., arredondado, velutino; hipanto 1-2 $\mathrm{mm}$ compr., globoso, velutino. Corola hipocrateriforme, prefloração imbricada, alvo-amarelada, tomentosa a serícea externamente e glabra a pubérula internamente; tubo 4,9-18 mm compr., lobos 2-4,5 $\mathrm{mm}$ compr., oblongos. Estames inclusos, inseridos junto à fauce, sésseis; anteras 1,8-2,3 mm compr. Ovário tetralocular, uniovulado, óvulos pêndulos; estilete $8-15 \mathrm{~mm}$ compr., inteiro, incluso, pubérulo; estigma capitado; disco inteiro, piloso. Drupa 3-6 $\mathrm{mm}$ compr., globosa, vilosa; pirênio globoso. Sementes 2,5-5 mm compr., oblongas.

Material selecionado: PARAÍBA: Cabaceiras, 15.IV.2008, fl., M.C. Pessoa \& J.R. Lima 296 (JPB). Caturité, 12.VII.2008, fr., M.C. Pessoa \& J.R. Lima 509 (JPB). Monteiro, 22.V.2008, fr., M.C. Pessoa \& P.C. Gadelha-Neto 401 (JPB). São José dos Cordeiros, 16.IV.2008, fr., M.C. Pessoa \& J.R. Lima 307 (JPB).

Guettarda angelica, conhecida popularmente como Angélica, é facilmente reconhecida no campo pelas inflorescências em cimas dicotômicas e pelas drupas globosas. É endêmica da caatinga, ocorrendo em toda a Depressão Sertaneja (Barbosa et al. 2010). No Cariri paraibano é frequente nas áreas ciliares e sobre lajedos. Floresce de janeiro a abril frutifica de abril a agosto.

\section{Guettarda sericea Müll. Arg., Flora 58: 450.} 1875.

Fig. $2 b$

Arbusto, ca. 2,5 m alt.; ramos cilíndricos, estriados, castanho-avermelhados ou acinzentado, lenticelados, glabros, seríceos quando jovens. Estípulas 5-7 mm compr., inteiras, triangulares, ápice aristado, externamente hirsuta, internamente com coléteres. Folhas opostas; lâmina 3,5-7,5 × 1-4 cm, oblonga ou raro elíptica, ápice agudo, base arredondada, margem revoluta, papirácea a cartácea, face superior pubescente, face inferior serícea, discolores; nervura principal proeminente, nervuras secundárias 6-9 pares; pecíolo 3-8 $\mathrm{mm}$ compr., seríceo. Cimas dicotômicas axilares, 5-7 flores; pedúnculo 1,5-3,2 cm compr., seríceo. Flores andróginas, 4-meras, sésseis; botões florais com ápice obtuso; Cálice truncado, 2-2,8 mm compr., com 1 lobo ca. $1 \mathrm{~mm}$ compr., arredondado, velutino a tomentoso; hipanto ca. $1 \mathrm{~mm}$ compr., globoso, tomentoso. Corola hipocrateriforme, prefloração imbricada, alvo-amarelada, tomentosa externamente e glabra internamente; tubo 5-10 $\mathrm{mm}$ compr., lobos 3-5 mm compr., oblongos. Estames inclusos, inseridos na porção mediana do tubo, subsésseis; anteras 1,8-3 mm compr. Ovário tetraloculado, lóculo uniovulado, óvulos pêndulos; estilete 2,5-4 $\mathrm{mm}$ compr., inteiro, incluso, anguloso pubescente; estigma capitado; disco inteiro, hirsuto a piloso. Drupa 5,5-12 mm compr., oblonga, vinácea, velutina; pirênio 4-10 $\mathrm{mm}$ compr., oblongo, fibroso. Sementes ca. 4,5 mm compr., oblongas.

Material examinado: PARAÍBA: Monteiro, 12.VI.2008, fr., M.C. Pessoa et al. 423 (JPB).

Material adicional: PARAÍBA: Sousa, 27.VI.1993, fl., P. C. Gadelha-Neto 46 (JPB).

G. sericea é endêmica da Caatinga, com referência para todo o Nordeste brasileiro (Barbosa et al. 2010). No Cariri foi coletada apenas no município de Monteiro, em áreas ciliares. Floresce e frutifica de abril a junho. G. sericea difere de $G$. angelica por apresentar frutos oblongos e folhas seríceas. É conhecida popularmente como Veludo.

10. Leptoscela ruellioides Hook. f., Hooker's Icon. Pl. 14: t. 1149. $1873 . \quad$ Fig. 2c-d

Subarbusto ereto, $0,5-1 \mathrm{~m}$ alt.; ramos cilíndricos ou ligeiramente angulosos, estriados, verdes, glabros a glabrescentes. Bainha estipular 0,7-1,6 mm compr., longo-fimbriada, vilosa, 12-14-laciniada, lacínios 1,3-3 mm compr., glandulosos. Folhas opostas, lâmina $2-3 \times 0,5-1$ $\mathrm{cm}$, elíptico-lanceolada, ápice acuminado, base cuneada, margem inteira, ciliada, cartácea, face superior escabra a pubescente, face inferior pubescente a híspida, hirsuta ao longo das nervuras; nervura principal proeminente na face inferior, nervuras secundárias 3-5 pares; pecíolo $1-1,5$ cm compr., pubescente a hirsuto. Monocásio escorpioide, axilar, multifloro; pedúnculo 1,5-4 $\mathrm{cm}$ compr., glabro. Flores andróginas, 5-mera, sésseis; botões florais com ápice obtuso. Cálice subulado, 5-laciniado, lacínios subiguais 1-1,8 $\mathrm{mm}$ compr., glabro, margem longo-ciliada; hipanto 0,6-1 mm compr., glabro. Corola infundibuliforme, prefloração valvar, lilás, externamente glabra, internamente pilosa com tricomas glandulosos longos formando um anel na base dos estames; 


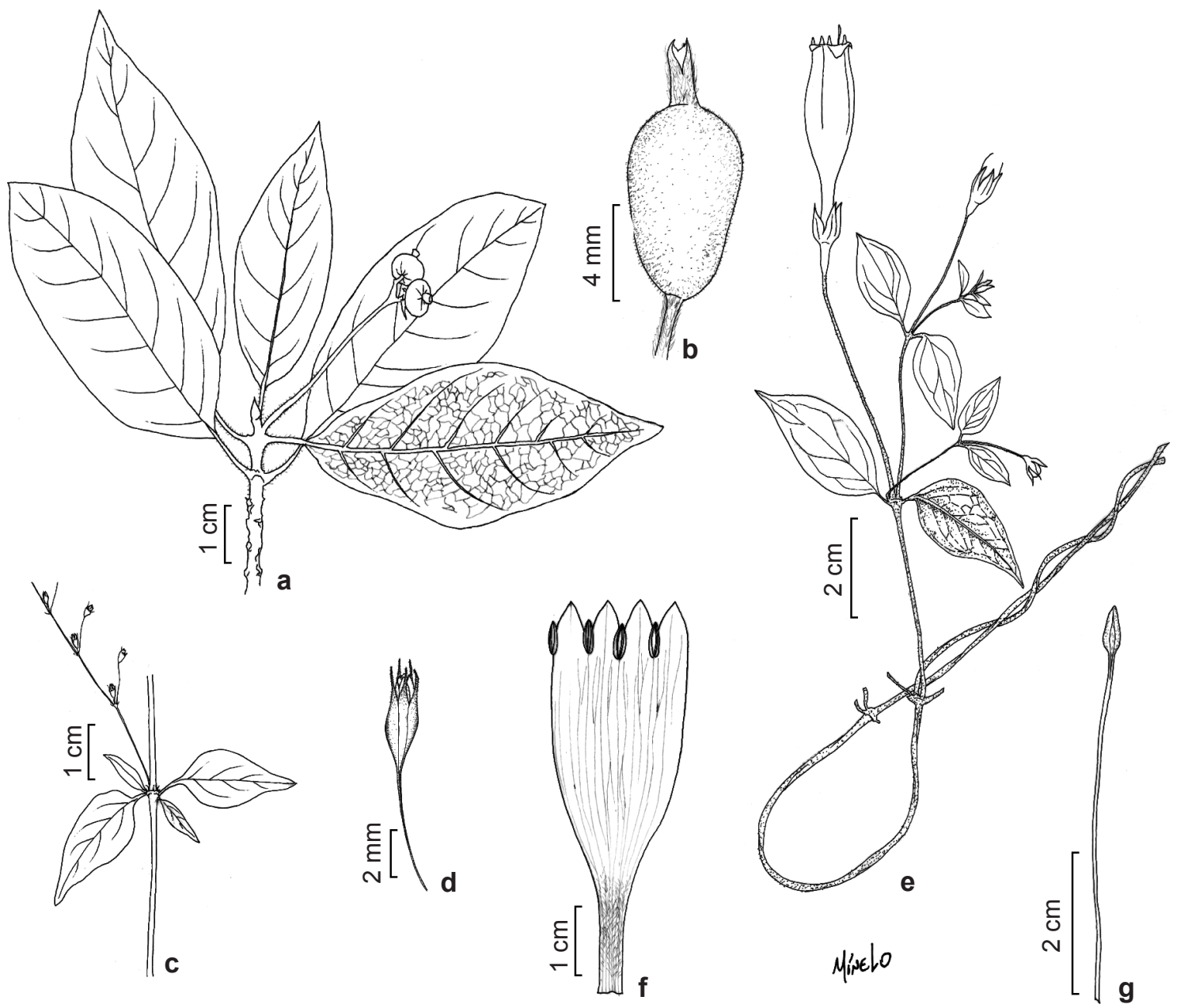

Figura 2 - a. Guettarda angelica - ramo florífero; b. Guettarda sericea - fruto; c-d. Leptoscela ruellioides - c. ramo florífero; d. fruto; e-g. Manettia cordifolia - e. ramo florífero; f. corola aberta; g. estilete e estigma. (a. M.C.Pessoa \& J.R. Lima 509; b. M.C.Pessoa et al. 423; c-d. M.C.Pessoa \& J.R. Lima 367; e-g. M.C.Pessoa et al. 449).

Figure 2 - a. Guettarda angelica - fertile branch; b. Guettarda sericea - fruit; c-d. Leptoscela ruellioides - c. fertile branch; d. fruit; e-g. Manettia cordifolia - e. fertile branch; f. open corolla; g. style and stigma. (a. M.C.Pessoa \& J.R.Lima 509; b. M.C.Pessoa et al. 423; c-d. M.C.Pessoa \& J.R.Lima 367; e-g. M.C.Pessoa et al. 449).

tubo 3,3-4 mm compr., lobos ca. $5 \mathrm{~mm}$ compr., triangulares. Estames inclusos, inseridos na porção mediana do tubo, subsésseis; anteras 1-1,2 mm compr.. Ovário bilocular, lóculo pluriovulado, óvulos aglomerados formando uma massa; estilete 5-6 mm compr., inteiro, incluso, pubérulo-papiloso; estigma bífido; disco inteiro, glabro. Cápsula septicida denticulada no ápice, 3,6-5,8 $\mathrm{mm}$ compr., glabra; lobos do cálice persistentes. Sementes $0,7-1 \mathrm{~mm}$ compr., ovadas a suborbiculares, exotesta fovéolada, papilosas, bissulcadas.

Material selecionado: PARAÍBA: Cabaceiras, 13.VII.2008, fl. e fr., M.C. Pessoa \& J.R. Lima 522
(JPB). Monteiro, 12.VI.2008, fl. e fr., M.C. Pessoa et al 427 (JPB). São João do Tigre, 17.V.2008, fl. e fr., M.C. Pessoa \& J.R. Lima 367 (JPB). São José dos Cordeiros, 16.IV.2008, fl. e fr., M.C. Pessoa \& J.R. Lima 304 (JPB)

Leptoscela ruellioides é uma espécie endêmica do Brasil, que ocorre em áreas de Caatinga e Cerrado da região Nordeste. É referida até o momento para a Paraíba, Pernambuco, Bahia, Alagoas e Sergipe (Jardim 2010). No Cariri paraibano foi encontrada apenas nos lajedos. Floresce e frutifica de abril a julho. Destaca-se pela inflorescência em monocásio, tipo escorpioide, e frutos capsulares denticulados no ápice. 
11. Manettia cordifolia Mart., Königl. Akad. Wissensch. München 9: 95, t. 7. 1824. Fig. 2e-g

Subarbusto escandente; ramos cilíndricos, verdes a castanhos, pubérulos. Estípulas 1,8-2,4 $\mathrm{mm}$ compr., triangulares, invaginantes, com ápice agudo, reflexo, 0,2-0,5 $\mathrm{mm}$ compr., pilosa, com coléteres na margem. Folhas opostas; lâmina 7-10 × 2,8-5 cm, ovado-lanceolada, raro suborbicular, ápice cuspidado a acuminado, base atenuada a cuneada, raro rotunda, margem ciliada, membranácea, face superior glabrescente, face inferior pubescente, nervura principal pouco evidente, nervuras secundárias 5-6 pares; pecíolo 0,5-1,5 cm compr., piloso. Fascículos ou flores isoladas axilares ou terminais, sésseis, paucifloros, 1-3 flores. Flores andróginas, 4-meras, pedicelo 4,5-5 cm compr., pubérulo; botões florais com ápice obtuso. Cálice subulado, 4-laciniado, lacínios subiguais $0,8-1 \mathrm{~cm}$ compr., interna e externamente glabro a glabrescente, ciliados; hipanto $3-5 \mathrm{~mm}$ compr., cupuliforme, glabro a glabrescente; Corola clavado-tubulosa, prefloração valvar, rubra, glabra externamente, internamente lanosa, com um anel de tricomas na base; tubo 3,7-5 cm compr., lobos 5-6 mm compr., triangulares. Estames inclusos, inseridos na fauce, subsésseis; anteras $5-6 \mathrm{~mm}$ compr. Ovário bilocular, lóculo pluriovulado; estilete 3,6-5,5 cm compr., inteiro, incluso ou exserto, glabro; estigma bífido, espatulado; disco inteiro, glabro. Cápsula septicida, oblonga, 11,2-18 $\mathrm{mm}$ compr. cálice persistente e marcescente (Macias 1998). Sementes aladas, 3,2-4,4 mm compr., oblongas (Macias 1998).

Material examinado: PARAIÍBA: São João do Tigre, 13.VI.2008, fl., M.C. Pessoa 449 (JPB).

Manettia cordifolia ocorre no Peru, Bolívia, Paraguai, Uruguai, Argentina e Brasil (Andersson 1992). Neste último está presente na Caatinga, Cerrado, Mata Atlântica ( Barbosa et al. 2010). No Cariri, foi coletada apenas no município de São João do Tigre, em área aberta. Flores e frutos foram observados nos meses de junho e julho. Destaca-se por sua corola clavado-tubulosa, rubra, e hábito escandente.

12. Mitracarpus baturitensis Sucre, Rodriguésia 26(38): 255. 1971.

Fig. 3a-c

Erva ereta, 8-40 cm alt., ramificada; caule tetrangular a subtetrangular, verde ou verdeamarelado, glabrescente ou pubérulo. Bainha estipular $0,5-5 \mathrm{~mm}$ compr., fimbriada, glabra ou pilosa, lacínios $5-8$, ca. $1 \mathrm{~mm}$ compr., não glandulosos. Folhas opostas, sésseis; lâmina $1-6,5 \times 0,1-0,7 \mathrm{~cm}$, estreito-elípticas a elípticas, ápice agudo, base atenuada, margem revoluta, membranácea ou cartácea, face superior escabra ou pubescente apenas nas nervuras, face inferior glabra, pubescente ao longo das nervuras; nervura principal proeminente, nervuras secundárias 2-3 pares. Glomérulos axilares e terminais, sésseis, multifloros; 2-4 brácteas foliáceas. Flores andróginas, 4-meras, sésseis a subsésseis; botões florais com ápice obtuso. Cálice subulado, 4-laciniado, lacínios desiguais dois a dois, os maiores 1,6-2 mm compr., maculados na porção central, os menores $1,3-1,5 \mathrm{~mm}$ compr., glabro, hialinos, paleáceos, margem ciliada; hipanto 0,6-2 mm compr., obovado, glabro. Corola hipocrateriforme, prefloração valvar, alva, externamente pubérulo-papilosa, internamente glabrescente com um anel de tricomas no terço inferior; tubo 1-2 mm compr., lobos 0,7-1,3 mm compr., ovados. Estames sub-inclusos a exsertos, inseridos junto à fauce, sésseis a subsésseis; filetes $0,2-0,3 \mathrm{~mm}$ compr., anteras $0,8-1 \mathrm{~mm}$ compr. Ovário bilocular, lóculo uniovulado; estilete 1-3 mm compr., inteiro, incluso ou exserto, glabro; estigma bífido; disco inteiro, glabro. Cápsula circuncisa, 0,8-1 mm compr., globosa, glabra a pubescente na porção opercular, glabra na porção basal; lobos do cálice persistentes. Sementes 0,5-0,8 mm compr., oblongas ou globosas, planoconvexas, exotesta fovéolo-reticulada, face dorsal com depressão cruciforme impressa, face ventral com depressão em forma de "X", prolongando-se lateralmente, coberta por estrofíolo.

Material selecionado: PARAÍBA: Cabaceiras, 22.IX.2007, fl., M.C. Pessoa et al. 209 (JPB). Caturité, 16.V.2008, fl., M.C. Pessoa \& J.R. Lima 344 (JPB).Monteiro, 12.VI.2008, fl., M.C. Pessoa et al. 438 (JPB).Serra Branca, 29.VII.2007, fl., M.C. Pessoa et al. 180 (JPB). São João do Cariri, 12.VII.2008, fl. e fr., M.C. Pessoa \& J.R. Lima 515 (JPB). São João do Tigre, 17.V.2008, fl., M.C. Pessoa \& J. R. Lima 354 (JPB). São José dos Cordeiros, 16.VIII.2007, fl. e fr., M.C. Pessoa et al. 185 (JPB).

É uma espécie com distribuição geográfica restrita ao Brasil, ocorrendo na Caatinga e Cerrado, no Distrito Federal e nos estados do Piauí, Ceará, Paraíba, Pernambuco, Bahia, Goiás e Mato Grosso (Souza et al. 2010). No Cariri paraibano, foi encontrada principalmente sobre os lajedos, ocorrendo também na caatinga sensu stricto e em áreas ciliares. Floresce e frutifica de abril a setembro. Suas sementes são parecidas com as de Mitracarpus frigidus Willd. ex Roem. \& Schult.), 

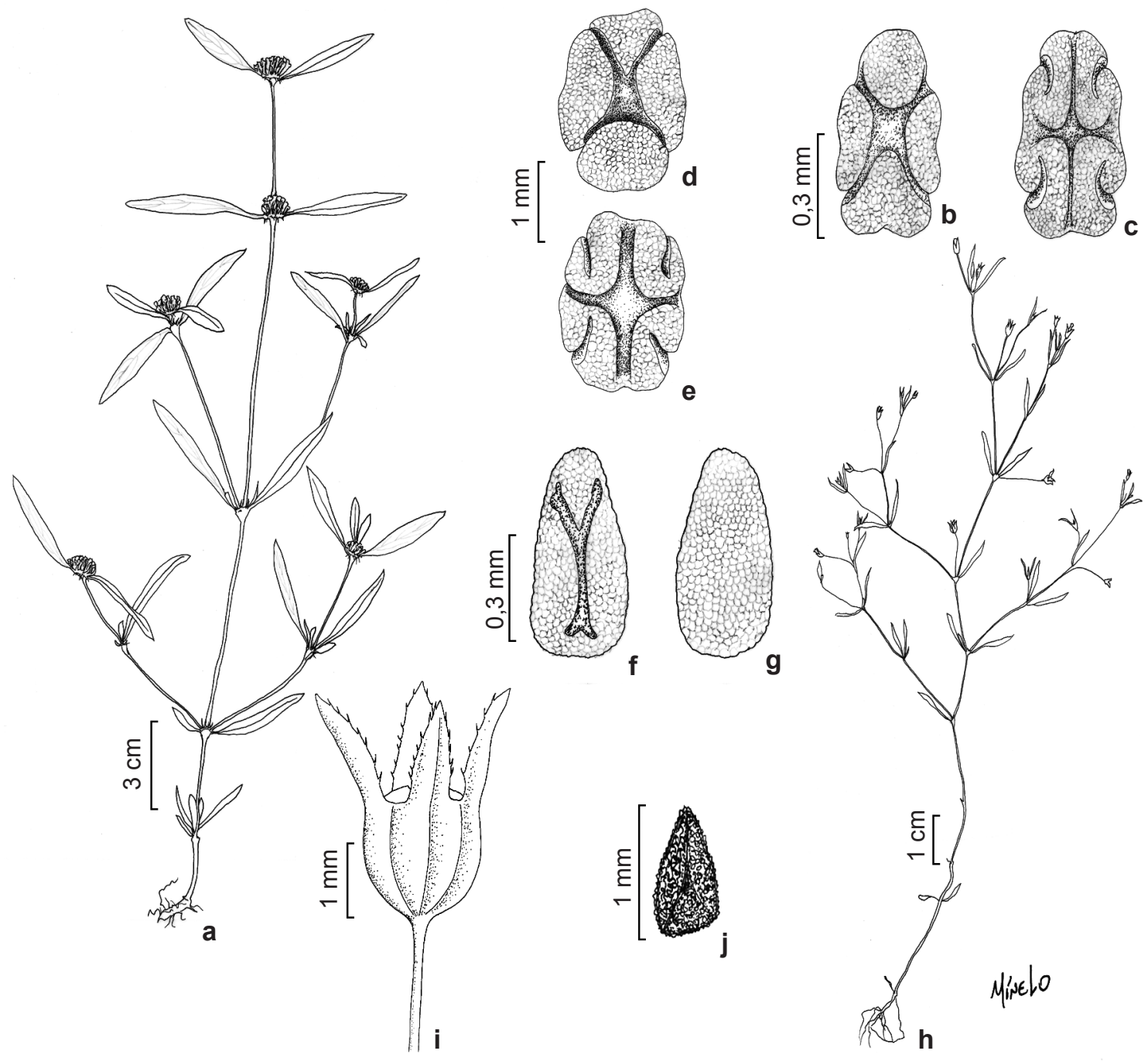

Figura 3 - a-c. Mitracarpus baturitensis - a. hábito; b. semente, face ventral; c. semente, face dorsal; d-e. Mitracarpus frigidus - d. semente, face ventral; e. semente, face dorsal. f-g. Mitracarpus salzmannianus - f. semente, face ventral; g. semente, face dorsal; h-j. Oldenlandia tenuis - h. hábito; i. fruto; j. semente, vista frontal. (a. M.C.Pessoa \& J.R.Lima 354; b-c. M.C.Pessoa et al. 180; d-e. M.C.Pessoa et al. 237; e-f. M.C.Pessoa \& J.R.Lima 536; h-j. M.C.Pessoa \& J.R.Lima 529).

Figure 3 - a-c. Mitracarpus baturitensis - a. habit; b. seed, ventral view; c. seed, dorsal face; d-e. Mitracarpus frigidus - d. seed, ventral face; e. seed, dorsal face; f-g. Mitracarpus salzmannianus - f. seed, ventral face; g. seed, dorsal face; $\mathrm{h}-\mathrm{j}$. Oldenlandia tenuis - h. habit; i. fruit; j.seed, frontal view. (a. M.C.Pessoa \& J.R.Lima 354; b-c. M.C.Pessoa etal. 180; d-e. M.C.Pessoa etal. 237; e-f. M.C.Pessoa \& J.R.Lima 536; h-j. M.C.Pessoa \& J.R.Lima 529).

mas M. baturitensis se distingue por outros caracteres, como porte herbáceo ( $v s$. subarbustivo), e folhas estreito-elípticas a elípticas ( $v s$. folhas lanceoladas a linear-lanceoladas).

13. Mitracarpus frigidus (Willd. ex Roem. \& Schult.) K. Schum., Fl. Bras. 6(6): 81. 1888.

Fig. 3d-e

Subarbusto ereto, $0,4-1 \mathrm{~m}$ alt.; ramos angulosos, estriados, castanho-avermelhado ou castanho-acinzentado, glabros ou pubérulos. Bainha estipular 1,6-2,9 mm compr., fimbriada, pilosa, 8-12-laciniada, lacínios 4,6-7 mm compr., glandulosos. Folhas opostas, sésseis; lâmina 3-6 $\times 0,6-1 \mathrm{~cm}$, lanceoladas a linear-lanceoladas, ápice agudo-mucronado, base atenuada, margem revoluta, cartácea, face superior glabra ou estrigosa, face inferior glabra ou hirsuta principalmente sobre a nervura principal; nervura principal proeminente, nervuras secundárias 3 pares. Glomérulos terminais, 
sésseis, multifloros; 2-4 brácteas foliáceas, geralmente reflexas. Flores andróginas, 4-meras, sésseis; botões florais com ápice arredondado. Cálice subulado, 4-laciniado, lacínios desiguais dois a dois, os maiores 3-4 mm compr., os menores 1,4-2 mm compr., subentendidos por lacínios glandulosos inconspícuos, margem longo-ciliada; hipanto 1-1,5 mm compr., turbinado, pubérulo. Corola hipocrateriforme, prefloração valvar, branca, externamente pubérulo-papilosa até a metade do tubo, internamente com um anel de tricomas delgado no terço inferior; tubo 4-5,5 mm compr., lobos 2-2,4 mm compr., triangulares. Estames exsertos, inseridos junto à fauce; filetes 0,5-1 mm compr., glabros; anteras 1,5-2 mm compr. Ovário bilocular, lóculo uniovulado; estilete 2,5-3 mm compr., inteiro, exserto, pubescente; estigma bífido; disco inteiro, papiloso. Cápsula circuncisa, 2-3 mm compr., obcônica, pubescente na porção opercular, glabra na porção basal; lobos do cálice persistentes. Sementes 1-1,5 mm compr., oblongas ou raro globosas, plano-convexas, exotesta foveolado-reticulada, face dorsal com depressão cruciforme profunda, face ventral com depressão em forma de "X", prolongando-se dorsalmente em duas depressões apical-laterais semi-circulares, cobertas por estrofíolo.

Material selecionado: PARAÍBA: Serra Branca, 29.VII.2007, fl., M.C. Pessoa et al. 178 (JPB), 17.X.2007, fl. e fr., M.C. Pessoa et al. 237 (JPB).

Mitracarpus frigidus ocorre na Colômbia, Venezuela, Guiana Francesa e Brasil (Souza et al. 2010). No Brasil ocorre desde o estado de Roraima, Amazonas até Santa Catarina (Delprete et al. 2005), com preferência por solos arenosos e afloramentos rochosos. No Cariri foi observada apenas no município de Serra Branca, em afloramentos rochosos. Floresce e frutifica junho a outubro. Mitracarpus frigidus é uma espécie bastante variável, apresenta características semelhantes a M. baturitensis, contudo pode ser diferenciada facilmente pelo porte subarbustivo ( $v s$. herbáceo).

14. Mitracarpus salzmannianus DC., Prodr. 4: 571. 1830.

Fig. $3 f-g$

Erva ereta, 0,15-1 m alt., ramificada; caule tetrangular, verde, híspido ou hirsuto. Bainha estipular 1,6-3 mm compr., fimbriada, pilosa, 9-12-laciniada, lacínios 2,4-3,4 mm compr., não glandulosos. Folhas opostas, sésseis; lâmina $3-4(6) \times 0,7-1,3(2,5) \mathrm{cm}$, elíptica a estreitamente elíptica, ápice agudo, base atenuada, margem ciliada, membranácea a cartácea, face superior densamente estrigosa, face inferior estrigosa; nervura principal proeminente, nervuras secundárias 5 pares. Glomérulos axilares ou terminais, sésseis, multifloros; 2-4 brácteas foliáceas. Flores andróginas, 4-meras; pedicelo 0,5-1 mm compr.; botões florais com ápice obtuso. Cálice subulado, 4-laciniado, hirsuto, lacínios 2-3 $\mathrm{mm}$ compr. ou desiguais dois a dois, os maiores 2-3 mm compr., verdes, e os menores 1-2 mm compr., hirsuto, hialinos, pilosos na margem, subentendidos por lacínios glandulosos inconspícuos; hipanto ca. $1 \mathrm{~mm}$ compr., turbinado, glabro. Corola hipocrateriforme, prefloração valvar, branca ou lilás, externamente pubérulo-papilosa, desde o terço superior até o terço médio, glabra no terço inferior, internamente com um anel de tricomas moniliformes no terço inferior; tubo 2,5-4,5 mm compr., lobos 1-1,2 mm compr., triangulares. Estames sub-inclusos a exsertos, inseridos junto à fauce; filetes $0,3 \mathrm{~mm}$ compr., glabros; anteras 0,6-0,7 mm compr. Ovário bilocular, lóculo uniovulado, óvulos presos ao septo. estilete 2,8-5,5 $\mathrm{mm}$ compr., inteiro, incluso ou exserto, glabro; estigma bífido; disco inteiro, papiloso. Cápsula circuncisa, ca. $1 \mathrm{~mm}$ compr., obovoide, pubescente na porção opercular, glabra na porção basal; lobos do cálice persistentes. Sementes 0,7-0,8 mm compr., oblongas, raro globosas, plano-convexas, exotesta fovéolo-reticulada, face dorsal sem depressões, face ventral com depressão em forma de "Y" invertido, sem prolongamentos dorsais, coberta por estrofíolo.

Material examinado: PARAÍBA: Cabaceiras, 13.VII.2008, fl. e fr., M.C. Pessoa \& J.R. Lima 520 (JPB). Monteiro, 22.V.2008, fl., M.C. Pessoa \& P.C. GadelhaNeto 399 (JPB). São João do Cariri, 12.VII.2008, fl., M.C. Pessoa \& J.R. Lima 514 (JPB). São José dos Cordeiros, 14.VII.2008, fl. e fr., M.C. Pessoa \& J.R. Lima 536 (JPB).

Mitracarpus salzmannianus é uma espécie amplamente distribuída no Brasil, Guiana, Suriname e Guiana Francesa. No Brasil, pode ser encontrada desde o nível do mar até $930 \mathrm{~m}$ de altitude, em ambientes de savana, restingas, tabuleiros costeiros e campos rupestres. (Souza et al. 2010). No Cariri paraibano foi encontrada em lajedos, ambientes ciliares e na caatinga sensu stricto. Floresce e frutifica de maio a julho. Diferencia-se das demais espécies de Mitracarpus presentes no Cariri paraibano pelas sementes com face dorsal sem depressões e face ventral com depressão em forma de "Y" invertido. 
15. Oldenlandia tenuis K. Schum., Fl. bras. 6(6): 273. 1889.

Fig. $3 h-j$

Erva ereta ou decumbente, 5-15 cm alt., ramificada; caule sub-tetrangular, delgado, verde, pubescente na base, glabro a glabrescente na porção apical. Bainha estipular ca. $0,5 \mathrm{~mm}$ compr., curto-fimbriada, pilosa na base, lacínios inúmeros, minúsculos, não glandulosos. Folhas opostas, sésseis; lâmina foliar, 3-10,8 × 0,4-1,3 mm, linear a lanceolada, ápice agudo, base atenuada, margem serreada na base, cartácea, glabra em ambas as faces; nervura principal proeminente, nervuras secundárias inconspícuas. Fascículo ou flores isoladas, axilares ou terminais, sésseis, paucifloros, 1-2 flores. Flores andróginas, 3-4 meras; pedicelo 4-7 mm compr., glabro; botões florais com ápice obtuso. Cálice subulado, 4-laciniado, lacínios 1,1-1,5 mm compr., glabro, margem denticulada; hipanto ca. 0,2 mm compr., cupuliforme, comprimido lateralmente, glabro a pubescente. Corola tubulosa, prefloração valvar, branca, glabra externamente, internamente com uma faixa de tricomas na base dos lobos; tubo $0,5-1,2$ $\mathrm{mm}$ compr., lobos $0,8-1 \mathrm{~mm}$ compr., triangulares a suborbiculares. Estames inclusos, inseridos junto à fauce, subsésseis; anteras ca. 0,5 mm compr. Ovário bilocular, lóculo pluriovulado, óvulos formando uma massa; estilete 0,4-0,6 mm compr., inteiro, incluso, glabro; estigma bilobado disco inconspícuo, inteiro, inteiro, glabro. Cápsula loculicida com deiscência apical, 1-1,8 mm compr., subglobosa, glabra; lobos do cálice persistentes. Sementes ca. $1 \mathrm{~mm}$ compr., piramidais, exotesta foveolada.

Material examinado: PARAÍBA: Cabaceiras, 13.VII.2008, fl. e fr., M.C. Pessoa \& J.R. Lima 529 (JPB). Serra Branca, 16.VI.2008, fl. e fr., M.C. Pessoa et al. 480 (JPB).

Ocorre na Guiana, Suriname, Guiana Francesa, Brasil, e no Noroeste da Venezuela (Andersson 1992; Steyermark 1988). No Brasil ocorre na Amazônia (Rondônia) e na Caatinga (Barbosa et al. 2010). No Cariri paraibano foi encontrada sobre lajedos. Floresce e frutifica nos meses de junho e julho.

\section{Randia armata (Sw.) DC., Prodr. 4: 387.} 1830.

Fig. $4 \mathrm{a}$

Arvoreta ou arbusto dioico, 1,6-3 m alt; ramos cilíndricos, estriados, castanho-avermelhados, espinescentes no ápice (4 espinhos), lenticelados. Estípulas livres, persistentes, 4-7 mm compr., inteiras, triangulares, ápice agudo, glabras externamente, internamente, com coléteres.
Folhas opostas; lâmina 11-16 × 4,5-8cm, obovada ou largamente lanceolada, ápice agudo, base atenuada, margem ligeiramente ondulada, ciliada, membranácea, face superior escabra, face inferior pubérula, pubescente a hirsuta ao longo das nervuras; nervura principal proeminente na face inferior, nervuras secundárias 6-9 pares; pecíolo 5-7 mm compr., hirsuto. Fascículos, terminal; pedúnculo delgado, muitas vezes piloso; 5 ou maisflora, brácteas subuladas, às vezes tripartidas; cálice 3-4 partido, lacínios subulados, externamente glabro ou pubérulos; corola hipocrateriforme, lacínios obtuso-oblíquos, glabros externamente. Estames inseridos na porção mediana do tubo; anteras brevemente apiculadas; estilete um pouco maior que o tubo, ápice espessado; estigma oblongo. Baga, ca. 1,8 cm compr., subglobosa, ligeiramente estriado, lobos do cálice persistentes. Sementes 1-1,3 cm compr., elípticas.

Material examinado: PARAÍBA: Monteiro, 12.VI.2008, fr., M.C. Pessoa et al. 422 (JPB).

Randia armata é encontrada desde o México, Guianas, Venezuela, Colômbia, Peru, Brasil até o Paraguai e também nas Índias Ocidentais. No Brasil ocorre na Amazônia, Caatinga, Cerrado e na Mata Atlântica (Barbosa et al. 2010). No Cariri está presente na caatinga sensu stricto e em áreas ciliares. Difere das demais espécies de Rubiaceae presentes no Cariri por apresentar ramos espinescentes no ápice. Foi encontrada com fruto, apenas uma vez, no mês de junho.

17. Richardia grandiflora (Cham. \& Schltdl.) Steud., Nomencl. Bot. (ed. 2) 2: 459. 1841.

Fig. 3b-d

Erva ou subarbusto prostrado, raro ereto, 30-60 cm alt., ramificado; caule tetrágono, verde, hirsuto. Bainha estipular ca. 3,3 mm compr., fimbriada, hirsuta, 6-8 lacíniada, lacínios ciliados, $3,8-12 \mathrm{~mm}$ compr., não glandulosos. Folhas opostas, lâmina $2-6,8 \times 2-2,8 \mathrm{~cm}$, lanceolada, ápice agudo, base atenuada, margem inteira, membranácea, escabra ou híspida em ambas as faces; nervura principal proeminente, nervuras secundárias 3-5 pares; pecíolo 5-6 $\mathrm{mm}$ compr., hirsuto. Flores andróginas, 5-6-meras, sésseis; botões florais com ápice obtuso ou semi-circular; Glomérulos terminais, sésseis, multifloros; 4 brácteas foliáceas. Cálice subulado, 6-laciniado, lacínios 6-7 mm compr., acuminados, longociliados, híspidos ou escabros; hipanto $1,2 \mathrm{~mm}$ compr., papiloso, glabro. Corola infundibuliforme, 
prefloração valvar, rósea; glabra externamente, internamente com um anel de tricomas no terço inferior; tubo 8-12 $\mathrm{mm}$ compr., lobos 4-6 $\mathrm{mm}$ compr., triangulares. Estames exsertos, inseridos junto à fauce; filetes ca. $1 \mathrm{~mm}$ compr.; anteras 1,2-1,5 mm compr. Ovário trilocular, lóculo uniovulado; estilete 10-12 mm compr., trífido no ápice, exserto, pubescente; estigma cocleariforme; disco inteiro, glabro. Esquizocarpo 1,8-2 mm compr., oblongo, 3 mericarpos, indeiscentes, muricado-papilosos na face dorsal. Sementes $1-1,7$ $\mathrm{mm}$ compr., plano-convexas, semi-cilíndricas, exotesta muricada, sulcadas na face ventral.

Material selecionado: PARAÍBA: Cabaceiras, 21.IX.2007, fl. e fr., M.C. Pessoa et al. 199 (JPB). Caturité, 12.VII.2008, fl., M.C. Pessoa \& J.R. Lima 512 (JPB). Monteiro, 22.V.2008, fl., M.C. Pessoa \& GadelhaNeto 398 (JPB). São João do Cariri, 12.VII.2008, fl., M.C. Pessoa \& J. R. Lima 517 (JPB). São João do Tigre, 17.V.2008, fl., M.C. Pessoa \& J.R. Lima 358 (JPB). São José dos Cordeiros, 16.VII.2007, fl., M.C. Pessoa \& J.R. Lima 188 (JPB).

Richardia grandiflora tem distribuição neotropical (Andersson 1992). No Brasil, é uma espécie ruderal frequente em todas as regiões. No Cariri paraibano é comum nos ambientes ciliares e na caatinga sensu stricto. Floresce e frutifica de abril a novembro. Caracteriza-se por apresentar inflorescências capitadas terminais, com brácteas involucrais, ovário trilocular, estilete trífido e frutos separando-se em três mericarpos muricados.

18. Spermacoce tenuior L., Sp. Pl. 1: 102.

Fig. $4 \mathrm{e}-\mathrm{k}$

Erva ereta, até $1 \mathrm{~m}$ alt., ramificada; caule tetrangular, verde-amarelado, barbelado ao longo dos ângulos. Bainha estipular 1,4-3 $\mathrm{mm}$ compr., longo fimbriada, pilosa, lacínios 5-11(15), 1,3-8,6 mm compr., glandulosos. Folhas opostas; lâmina 3,2-9,5 × 0,8-4 cm, elíptica, ovada-lanceolada a lanceolada, ápice agudo a acuminado, base atenuada, margem serrilhada, membranácea, face superior estrigosa a escabra, face inferior barbada ao longo das nervuras; nervura principal proeminente, nervuras secundárias 6-8 pares; pecíolo canaliculado 0,4$1,5 \mathrm{~cm}$ compr. Glomérulos axilares ou terminais, sésseis, paucifloros; 2-4 brácteas foliáceas. Flores andróginas, 4-meras, sésseis a subsésseis; botões florais com ápice obtuso. Cálice subulado, 4-laciniado, lacínios desiguais, um maior 1,6-1,8 $\mathrm{mm}$ compr., e os demais subiguais $1,2-1,4 \mathrm{~mm}$ compr., pubérulo-papiloso, margem ciliada; hipanto 1,8-2,3 mm compr., com um tufo de pêlos longos e densos, concentrado em um dos lados na porção apical. Corola tubulosa, prefloração valvar, branca, papilosa externamente, internamente com tricomas longos e densos, moniliformes, no $2 / 3$ superior do tubo, base do tubo e lobos glabros; tubo $1-1,5 \mathrm{~mm}$ compr., lobos $0,7-1 \mathrm{~mm}$ compr., triangulares. Estames inclusos, inseridos na base do tubo, subsésseis; anteras $0,1-0,2 \mathrm{~mm}$ compr. Ovário bilocular, lóculo uniovulado; estilete ca. 0,2 $\mathrm{mm}$ compr., muito curto, inteiro, incluso, papiloso; estigma capitado; disco inteiro, papiloso. Cápsula septicida 2-3 mm compr., elipsoide, com um tufo de tricomas longos e densos, concentrado em um dos lados na porção apical, carpelos unidos na base, um mericarpo indeiscente, e outro deiscente, abrindo-se parcialmente do ápice até a região mediana; lobos do cálice persistentes. Sementes 1,5-2 mm compr., oblongas a ovadas, exotesta fovéolo-reticulada, sulcos transversais ausentes, sulco ventral coberto pelos estrofíolos.

Material selecionado: PARAÍBA: Camalaú, 14.VI.2008, fl. e fr., M.C. Pessoa \& J.R. Lima 538 (JPB).Caturité, 16.V.2008, fl. e fr., M.C. Pessoa \& J.R. Lima 346 (JPB). Monteiro, 22.V.2008, fl. e fr., M.C. Pessoa et al. 403 (JPB).

Spermacoce tenuior está presente em toda a América Tropical e Subtropical. No Brasil ocorre na Caatinga, Cerrado e Mata Atlântica (Barbosa et al. 2010). No Cariri paraibano, ocorre apenas em áreas ciliares. Floresce e frutifica de maio a julho. Diferencia-se das demais espécies presentes na região pelo tipo de deiscência do fruto, com uma porção indeiscente e outra parcialmente deiscente, abrindo-se do ápice até a região mediana.

19. Staelia virgata (Link ex Roem. \& Schult.) K. Schum., Fl. Bras. 6(6): 76. $1889 . \quad$ Fig. 41

Erva ou subarbusto, ereto ou prostrado, 10-50 $\mathrm{cm}$ alt., ramificado; ramos tetrágonos, cilíndricos na base, estriados, verdes a amarelo-esverdeados, pubescentes a vilosos. Bainha estipular 1,6-2,5 mm compr., fimbriada, pubérula ou hirsuta, lacínios 7-12, 1-3 mm compr., glandulosos. Folhas opostas, sésseis; lâmina $1,8-4,5 \times 0,2-0,5 \mathrm{~cm}$, linear a estreitamente elíptica, ápice agudo, base atenuada, margem revoluta, membranácea, face superior glabra ou glabrescente, pilosa próximo a base, face inferior estrigosa ou escabra nas nervuras; nervura principal evidente, nervuras secundárias 2-3 pares. Glomérulos axilares, raro terminais, sésseis, multifloros,; 2-(3) brácteas foliáceas. Flores 


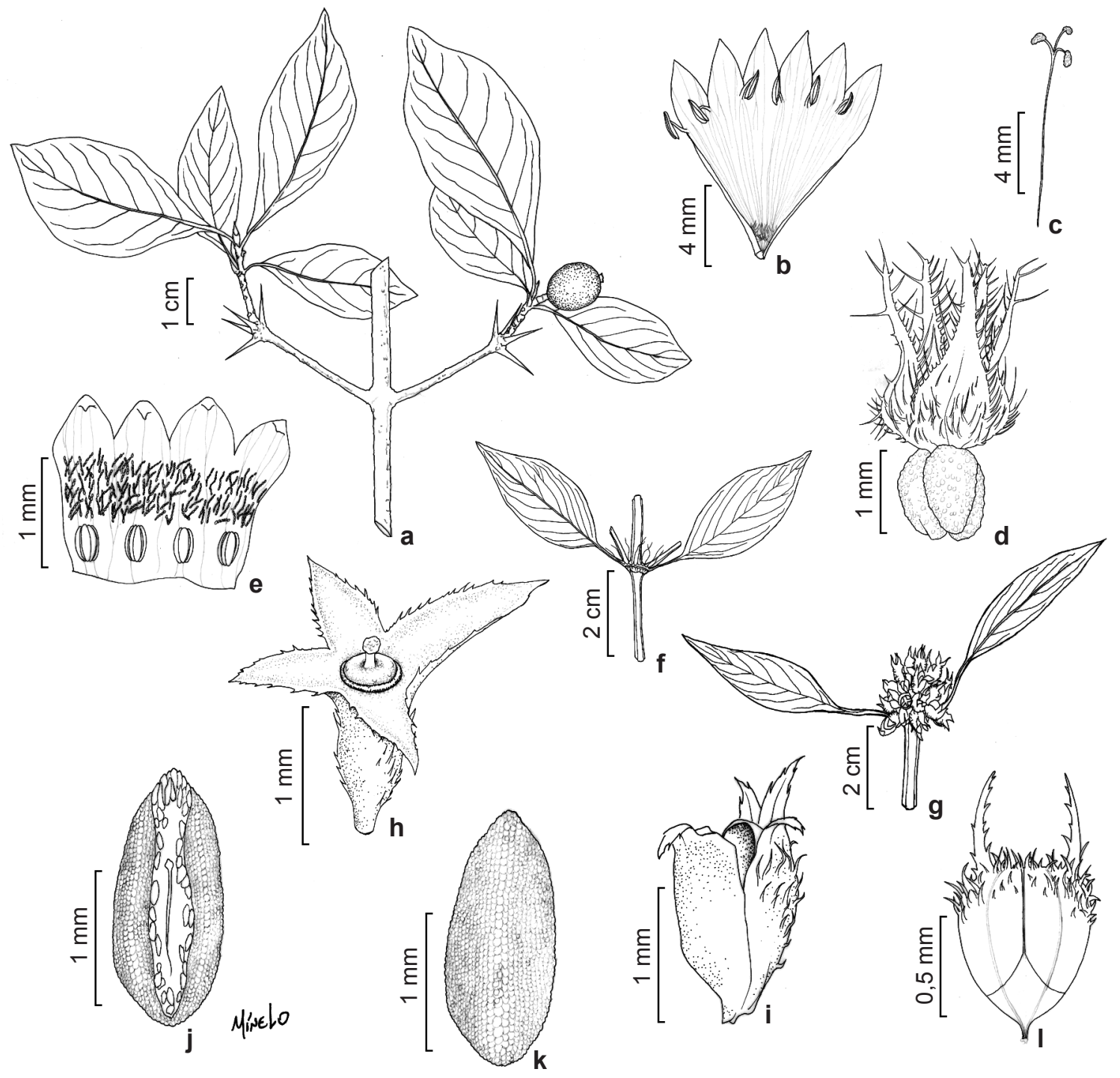

Figura 4 - a. Randia armata - a. ramo frutífero; b-d. Richardia grandiflora - b. corola aberta; c. estilete e estigma; d. fruto; e-k. Spermacoce tenuior - e. corola aberta; f. estípula; g. ramo com frutos; h. flor com corola removida; i. fruto; j. semente, face ventral; k. semente, face dorsal; 1. Staelia virgata - fruto. (a.M.C.Pessoa et al. 422; b-d. M.C.Pessoa et. al. 199; e. M.C.Pessoa \& J.R.Lima 538 (JPB); f-g. M.C.Pessoa \& P.C.Gadelha-Neto 403 (JPB); h. M. C. Pessoa \& J.R.Lima 538 (JPB); i. M.C.Pessoa \& P.C.Gadelha-Neto 403; j-k. M. C.Pessoa \& J.R.Lima 538 (JPB); 1. M.C.Pessoa et. al. 183.

Figura 4 -a. Randia armata - a. fertile branch; b-c. Richardia grandiflora - b. open corolla; c. style and stigma; d. fruit; e-k. Spermacoce tenuior-e. open corolla; f. stipule; g. branch with fruits; $h$. flower with corolla removed; i. fruit; $j$. seed, ventral face; $k$. seed, dorsal face; 1 . Staelia virgata - fruit. (a. M.C.Pessoa et al. 422; b-d. M.C.Pessoa et. al. 199; e. M.C. Pessoa \& J.R.Lima 538 (JPB); f-g. M.C.Pessoa \& P.C.Gadelha-Neto 403 (JPB); h. M. C.Pessoa \& J.R.Lima 538 (JPB); i. M.C.Pessoa \& P.C. Gadelha-Neto 403; j-k. M. C.Pessoa \& J.R.Lima 538 (JPB); 1. M.C.Pessoa et. al. 183.

andróginas, 4-meras, sésseis; botões florais com ápice obtuso. Cálice subulado, 2-laciniado, lacínios 1,3-2 mm compr., com 2 dentículos glandulosos interpostos, pubérulo a escabro, margem ciliada; hipanto ca. $1 \mathrm{~mm}$ compr., turbinado, estrigoso ou viloso. Corola infundibuliforme, prefloração valvar, branca ou lilás, externamente pubérula, internamente com um anel de tricomas no terço inferior; tubo 3-6 mm compr., lobos 1-2,8 $\mathrm{mm}$ compr., ovados. Estames exsertos, inseridos junto à fauce; filetes 1,2-1,5-2 mm compr.; anteras $0,8-1$ $\mathrm{mm}$ compr. Ovário bilocular, lóculo uniovulado, óvulos presos ao septo; estilete 4-8 $\mathrm{mm}$ compr., inteiro, exserto, glabro; estigma bífido; disco inteiro, 
glabro. Cápsula septicida, deiscência transversooblíqua, 1-2 mm compr., oblonga ou obovada, pilosa no ápice; lobos do cálice persistentes. Sementes 1-1,8 mm compr., obovadas, planoconvexas, exotesta fovéolo-papilada, face ventral sulcada ao redor do estrofíolo.

Material selecionado: PARAÍBA: Serra Branca, 29.VII.2007, M.C. Pessoa et al. 183 (JPB). São João do Tigre, 17.V.2008, M.C. Pessoa \& J.R. Lima 353 (JPB).

Staelia virgata tem distribuição ampla, ocorrendo em parte do território do Peru, Bolívia, Paraguai, até o norte da Argentina (Andersson 1992). No Brasil ocorre em todos os domínios fitogeográficos, exceto no Pampa (Souza \& Sales 2004; Barbosa et al. 2010). No Cariri paraibano é bastante frequente sobre os lajedos. Seu fruto é característico, com deiscência tranverso-oblíqua, caráter que pode ser utilizado para diferenciá-la das demais espécies de Rubiaceae no Cariri Paraibano. Floresce e frutifica de abril a agosto.

20. Tocoyena formosa (Cham. \& Schltdl.) K. Schum., Fl. bras. 6(6): 347. 1889.

Árvore ou arvoreta $2-7 \mathrm{~m}$ alt.; ramos cilíndricos, estriados, castanho-avermelhados a acinzentados, lenticelados, glabros, tomentosos no ápice. Estípulas 3,5-8,5 mm compr., inteiras, triangulares, ápice agudo a ligeiramente falcado, glabrescente a pubescente externamente, internamente com coléteres. Folhas opostas; lâmina 7,5-18 × 4-8 cm, largamente lanceolada a oblongo-lanceolada, ápice agudo, base atenuada a aguda, margem revoluta, cartácea a subcoriácea, pubescente na face superior, lanosa a densotomentosa na face inferior; nervura principal proeminente na face inferior, nervuras secundárias 7-9 pares; pecíolo 1-2 mm compr., tomentoso. Dicásios terminais, sésseis ou curto pedunculados, 4-8 flores; pedúnculo ca. $4 \mathrm{~mm}$, tomentoso. Flores andróginas, 5-meras, sésseis; botões florais com ápice agudo a acuminado. Cálice campanulado, com ápice denticulado, 1-3 $\mathrm{mm}$ compr., tomentoso, internamente com coléteres; hipanto 6,8-9 mm compr., obovado, tomentoso. Corola hipocrateriforme, prefloração contorta, amarela, tomentosa externamente e glabra internamente, vilosa apenas na fauce; tubo 6-12 cm compr., lobos 1,4-2 cm compr., oblongos a obovados. Estames exsertos, inseridos à fauce; filetes ca. 1-2 mm compr., glabros; anteras 5-7 mm compr. Ovário bilocular, lóculo pluriovulado, óvulos presos no septo; estilete 9-12,5 cm compr., inteiro, exserto, glabro; estigma bilamelado; disco inteiro, glabro.
Baga 2,6-5 cm compr., globosa a subglobosa, pubérula a híspida; persistentes. Sementes $0,7-1$ cm compr., discoides, dispostas horizontalmente. Material selecionado: PARAÍBA: Cabaceiras, 21.IX.2007, fr., M.C. Pessoa et al. 205 (JPB). São José dos Cordeiros, 06.II.2007, fl., M.C. Pessoa \& J.R. Lima 109 (JPB). Serra Branca, 17.X.2007, fr., M.C. Pessoa et al. 241 (JPB).

Tocoyena formosa tem distribuição neotropical, ocorrendo amplamente na América do Sul (Delprete 2008). No Cariri Paraibano, é encontrada em lajedos, na caatinga sensu stricto e em áreas ciliares. Floresce de fevereiro a abril e frutifica em setembro e outubro. Os frutos permanecem na planta de um ano para o outro, sendo frequentemente observada predação dos mesmos. Tocoyena formosa difere de Tocoyena sellowiana por apresentar folhas com indumento e estípulas caducas, enquanto que na última as folhas são glabras e as estípulas persistentes.

21. Tocoyena sellowiana (Cham. \& Schltdl.) K. Schum., Fl. bras. 6(6): 349. 1889.

Arvoreta 2-5,5 m alt.; ramos cilíndricos, acinzentados, castanho-avermelhados, estriados, os mais jovens, glabros, lenticelados na porção apical. Estípulas persistentes, 4-7 mm compr., inteiras, triangulares, ápice agudo a ligeiramente falcado, glabras externamente, internamente apresentando coléteres. Folhas opostas; lâmina 11-16 × 4,5-8 $\mathrm{cm}$, obovada a largamente lanceolada, ápice agudo ou falcado, base ligeiramente atenuada a aguda, margem revoluta, cartácea, glabra, lustrosa na face superior; nervura principal proeminente na face inferior, nervuras secundárias 6-9 pares; pecíolo 1-1,8 mm compr., glabro. Dicásios terminais, sésseis ou pedunculados, 6-8 flores; pedúnculo 4-10 mm compr., glabro, lenticelado. Flores andróginas, 5-meras, sésseis; botões florais com ápice agudo a acuminado. Cálice campanulado, com ápice denticulado, $1-2 \times 3-5 \mathrm{~mm}$, glabro; hipanto 4-6 mm compr., obovado, glabro. Corola hipocrateriforme, prefloração contorta, amarela, glabra externamente e internamente vilosa apenas na fauce; tubo 10,5-12,5 cm compr., lobos 1,4-2 cm compr., oblongos a rotundos. Estames exsertos, inseridos na fauce, sésseis a subsésseis; anteras ca. $8 \mathrm{~mm}$ compr. Ovário bilocular, lóculo pluriovulado, estilete 11-14 cm compr., inteiro, exserto, glabro; estigma bilamelado; disco inteiro, glabro. Baga 2,7-5,6 cm, compr., globosa a subglobosa, glabra; lobos do cálice persistentes. Sementes $0,7-1 \mathrm{~cm}$ compr., discoides, dispostas horizontalmente. 
Material selecionado: PARAÍBA: Cabaceiras, 15.IV.2008, fl. e fr., M.C. Pessoa 291 (JPB). São José dos Cordeiros, 16.II.2008, fl. e fr., M.C. Pessoa 275 (JPB). Serra Branca, 17.II.2008, fl., M.C. Pessoa 279 (JPB).

Tocoyena sellowiana tem distribuição neotropical, e ocorre amplamente no Brasil (Andersson 1992). No Cariri paraibano ocorre sobre lajedos e áreas ciliares. Floresce de fevereiro a abril e frutifica em setembro e outubro. Caracteriza-se por apresentar folhas glabras lustrosas e estípulas persistentes, caracteres que a diferenciam de $T$. formosa.

\section{Agradecimentos}

Ao CNPq/Pesquisas Ecológicas de Longa Duração - Caatinga, a bolsa de mestrado de M.C.R. Pessoa e de produtividade de M.R.V. Barbosa, e o apoio financeiro através do Projeto PELD Caatinga. Aos curadores dos Herbários visitados, a presteza durante a consulta das coleções. Aos proprietários da RPPN Fazenda Almas, da RPPN Fazenda Santa Clara, do Lajedo do Pai Mateus, e do Refúgio da Serra a autorização de estudos em suas respectivas áreas. Ao Dr. William Wayt Thomas a revisão do Abstract, e aos dois revisores ad hoc que contribuíram para a melhoria do manuscrito original.

\section{Referências}

Andersson, L. 1992. A provisional checklist of neotropical Rubiaceae. Scripta Botanica Belgica 1: 1-199.

Bacigalupo, N.M.; Cabral, E.L. 2006. Nuevas combinaciones en el género Diodella (Rubiaceae, Spermacoceae). Darwiniana 44: 98-104.

Barbosa, M.R.V. 1995. The genus Guettarda in northeast of Brazil. Scripta Botanica Belgica 11: 62.

Barbosa, M.R.V. 1996. Estudo florístico e fitossociológico da Mata do Buraquinho, remanescente de Mata Atlântica em João Pessoa, PB. Tese de Doutorado. Universidade de Campinas, Campinas. 135p.

Barbosa, M.R.V. 1997. Nova espécie de Guettarda L. (Rubiaceae, Guettardeae). Bradea 8: 61-63.

Barbosa, M.R.V.; Lima, I.B.; Lima, J.R.; Cunha, J.P.; Agra, M.F. \& Thomas, W.W. 2007. Vegetação e flora no Cariri paraibano. Oecologia brasiliensis 11: 313-322.

Barbosa, M.R.V.; Sousa, E.B.; Jardim, J.G. 2006 Rubiaceae. In: Barbosa, M.R.V.; Sothers, C.; Mayo, S.; Gamarra-Rojas, C.F.L.; Mesquita, C.A. 2006. Checklist das plantas do nordeste brasileiro: angiospermas e gymnospermas. Ministério da Ciência e Tecnologia. Pp.135-140.

Barbosa, M.R.V. \& Zappi, D. 2002. Distribuição das espécies de Rubiaceae na caatinga. In: Sampaio, E.V.S.B.; Giulietti, A.M.; Virginio, J. \& Gamarra-
Rojas, C.F.L. (coords.). Vegetação e flora da caatinga. Associação Plantas do Nordeste e Centro Nordestino de Informação sobre Plantas, Recife. Pp.155-157.

Barbosa, M.R.; Zappi, D.; Taylor, C.; Cabral, E; Jardim, J.G.; Pereira, M.S.; Calió, M.F.; Pessoa, M.C.R.; Salas, R.; Souza, E.B.; Di Maio, F.R.; Macias, L.; Anunciação, E.A.; Germano Filho, P. 2010. Rubiaceae In: Forzza, R.C. et al. (orgs.). Lista de espécies da flora do Brasil. Jardim Botânico do Rio de Janeiro. Disponível em <http://floradobrasil.jbrj. gov.br/2010/FB000210>. Acesso em 20 Jun 2010.

Cabral, E.L. \& Bacigalupo, N.M. 1999. Estudio de las espécies americanas de Borreria series Laeves (Rubiaceae-Spermacoceae). Darwiniana 37: 259-277.

Cabral, E.L. \& Bacigalupo N.M. 2005. Novelties in Spermacoceae (Rubiaceae) from Bolivia and Paraguay. Brittonia 57: 129-140.

Lima, P.J. \& Heckendorff, W.D. 1985. Climatologia. In: Governo do Estado da Paraíba/Secretaria da Educação/UFPB. Atlas Geográfico do Estado da Paraíba. Ed. Grafset, João Pessoa. Pp. 34-43.

Delprete, P.G. 2008. Revision of Tocoyena (Rubiaceae: Gardenieae) from the states of Goiás and Tocantins and a new species endemic to white-sand areas in the brazilian cerrado. Journal of Botany Institute. Texas 2: 983-993.

Delprete, P.; Smith, L.B. \& Klein, R.M. 2005. Rubiáceas, Vol. 2. Gêneros de G-Z. In: Reis, A. (ed.). Flora ilustrada catarinense. I Parte, Monografia RUBI. Herbário Barbosa Rodrigues, Itajaí. Pp. 345-843.

IUCN 2001. IUCN Red list categories and criteria: Version 3.1. IUCN Species survival comission. IUCN, Gland, Cambridge. 30p.

Jardim, J.G. 2010. Leptoscela In: Forzza, R.C. et al. (orgs.). Lista de espécies da flora do Brasil. Jardim Botânico do Rio de Janeiro. Disponível em $<$ http:// floradobrasil.jbrj.gov.br/2010/FB026073)>. Acesso em 20 Jun 2010.

Jung-Mendaçolli, S.L. 1999. Flora fanerogâmica da Ilha do Cardoso (São Paulo, Brasil) Rubiaceae. In: Melo, M.M.R.F. (ed.). Flora fanerogâmica da Ilha do Cardoso. Vol. 6. Instituto de Botânica. São Paulo. Pp. 45-136.

Jung-Mendaçolli, S.L. \& Anunciação, E.A. 2007. Randia L. In: Wanderley, M.G.L.; Shepherd, G.J.; Melhem, T.S. \& Giulietti, A.M. (coords.). Flora fanerogâmica do estado de São Paulo. Instituto de Botânica, São Paulo. Vol. 5. Pp. 412-414.

Lima, A.G.M. \& Melo, A.M.B.L. 1985. Relevo. In: Atlas Geográfico do Estado da Paraíba. Governo do Estado da Paraíba/Secretaria da Educação/UFPB, Grafset, João Pessoa. 29p.

Lorence, D. H. 1999. A nomenclator of Mexican and Central American Rubiaceae. Monogr. Syst. Bot. Missouri Botanical Garden 73: 1-177. 
Macias, L.F.N. 1998. Estudos taxonômicos do gênero Manettia Mutis ex L. (Rubiaceae) no Brasil, Paraguai, Argentina e Uruguai. Tese de Doutorado. Universidade de Campinas, São Paulo. 356p.

Melo, A.S. de \& Barbosa, M.R.V. 2007. O gênero Borreria G. Mey (Rubiaceae) na Mata do Buraquinho, João Pessoa, Paraíba. Revista Brasileira de Biociências, 5: 627-629.

Moreira, E.R.F. 1988. Mesorregiões e microrregiões da Paraíba. Delimitação e caracterização. GAPLAN, João Pessoa. 74p.

Pereira, M.S. 1996. O gênero Psychotria L. (Rubiaceae) na Paraíba, Brasil. Monografia de Graduação. Universidade Federal da Paraíba, João Pessoa. 73p.

Pereira, M.S. \& Barbosa, M.R.V. 2004. A família Rubiaceae na Reserva Biológica Guaribas, Paraíba, Brasil. Subfamílias Antirheoideae, Cinchonoideae e Ixoroideae. Acta Botanica Brasilica 18: 305-318.

Pereira, M.S. \& Barbosa, M.R.V. 2006. A família Rubiaceae na reserva Biológica Guaribas, Paraíba, Brasil. Subfamília Rubioideae. Acta Botanica Brasilica 20: 455-470.

Persson, C. 2000. Phylogeny of the Neotropical Alibertia Group (Rubiaceae), with Emphasis on the Genus Alibertia, Inferred from its and 5S Ribosomal DNA Sequences. American Journal of Botany 87: 1018-1028.
Radford, A.E.; Dickison, W.C.; Massey, J.R.; Bell, C.R. 1974. Vascular plant systematics. Harper \& Row Publishers, New York. 891p.

Schumann, K. 1889. Rubiaceae. In: C.F.P. Martius (ed.). Flora brasiliensis 6: 124-466.

Souza, E.B.; Cabral, E.L. \& Zappi, D.C. 2010. Revisão de Mitracarpus (Rubiaceae - Spermacoceae) para o Brasil. Rodriguésia 61: 319-352.

Souza, E.B. \& Sales, M.F. 2004. O gênero Staelia Cham. \& Schltdl. (Rubiaceae - Spermacoceae) no estado de Pernambuco, Brasil. Acta Botanica Brasilica 18: 919-926.

Steyermark, J.A. 1988. Notes on Oldenlandia filicaulis and Oldenlandia tenuis (Rubiaceae). Annals of the Missouri Botanical Garden 75: 736-738.

SUDEMA. 1992. Paraíba 92: perfil ambiental e estratégia. Superintendência de Administração do Meio Ambiente, João Pessoa.

Velloso, A.L.; Sampaio, E.V.S. \& Pareyn, F.G.C. 2002. Ecorregiões propostas para o bioma Caatinga. Associação Plantas do Nordeste, Instituto de Conservação Ambiental, The Nature Conservancy do Brasil, Recife. 76p

Zappi, D.C. \& Stannard, B.L. 1995. Rubiaceae. In: Stannard, B.L. (coord.). Flora do Pico das Almas, Chapada Diamantina, Bahia, Brazil. Royal Botanic Gardens, Kew. Pp. 546-578. 
